\title{
JUDGE JOHN HOLLAND AND THE VICE- ADMIRALTY COURT OF THE CAPE OF GOOD HOPE, 1797-1803: SOME INTRODUCTORY AND BIOGRAPHICAL NOTES (PART 2)*
}

\author{
JP van Niekerk**
}

\section{ABSTRACT}

A British Vice-Admiralty Court operated at the Cape of Good Hope from 1797 until 1803. It determined both Prize causes and (a few) Instance causes. This Court, headed by a single judge, should be distinguished from the ad hoc Piracy Court comprised of seven members of which the Admiralty judge was one, and which sat twice during this period - and also from the occasional naval courts martial which were called at the Cape. The Vice-Admiralty Court's Judge, John Holland, and its main officials and practitioners were sent out from Britain.

Keywords: Vice-Admiralty Court; Cape of Good Hope; First British Occupation of the Cape; jurisdiction; Piracy Court; naval courts martial; Judge John Holland; other officials, practitioners and support staff of the Vice-Admiralty Court

* Continued from (2017) 23(2) Fundamina 176-210.

** Professor, Department of Mercantile Law, School of Law, University of South Africa. 


\section{The personnel of the Cape Vice-Admiralty Court}

The Vice-Admiralty Court at the Cape was staffed by a single judge, who, assisted by a registrar and his deputy, as well as a marshal, was in charge of its proceedings. Prosecutions were brought by the King's proctor, and practitioners (advocates and proctors ${ }^{138}$ ) appeared before it. It is to these and other officials that the spotlight will now turn. ${ }^{139}$

\section{Judge John Holland}

With the creation of a Vice-Admiralty Court at the Cape of Good Hope in January 1797, John Holland was appointed by Letters Patent, under the Great Seal of the High Court of Admiralty, to be its first and sole judge. ${ }^{140}$

Little is known of his early life. There is mention of a John Holland, probably our man, born in 1757 (other sources have 1758), "of Old Bailey", who was a lawyer in London in the $1770 \mathrm{~s}$ and $1780 \mathrm{~s}^{141}$ and it is known that his father and one of his brothers - he was the third son - were architects. ${ }^{142}$ In any event, John Holland arrived at the Cape on board the Belvedere more than a year later, on 3 February 1798, accompanied by his wife Catherine, née Eden. ${ }^{143}$ His arrival, according to Lady Anne Barnard, had been "anxiously expected for some time past" as he was "to

138 In some Vice-Admiralty courts, including, it seems, the one at the Cape, advocates (the Admiralty equivalent of barristers) were also allowed to act as proctors (the Admiralty equivalent of solicitors). Admitted advocates of such courts were also on occasion appointed as surrogates to perform the ordinary or common (but no other) acts of the judge in his absence, eg, administering oaths, decreeing monitions, or taking bail.

139 For lists of those who served on or were involved with the Court, see the African Court Calendar for 1801 and for 1802 .

140 See Philip 1981: 185.

141 He was admitted to Lincoln's Inn in 1773, and his name appears in the Law List for 1787 as counsel of King's Bench Walk, Inner Temple: see Ed Pope History, sv "Holland John", available at http://www.edpopehistory.co.uk (accessed 17 Aug 2015).

142 Barnard Diaries vol 1: 318 (4 Nov 1799) refers to Judge Holland being "the son of one architect \& certainly the brother of one". The brother was the architect Henry Holland (1745-1806), eldest son of Henry Holland (1712-1785), who was a prosperous Georgian builder who executed much of the architectural work of the celebrated landscape gardener Lancelot (Capability) Brown. Henry jr was at first in partnership with Brown (until the latter's death in 1783), and had married the latter's elder daughter in 1773. Their collaboration resulted in several well-known buildings. $\mathrm{He}$ subsequently established himself independently and received several royal commissions (including Carlton House in Pall Mall, Brighton and York House in Whitehall, the Theatre Royal in Drury Lane, and the Covent Garden Theatre). Brother Henry was also a collector of antiques, especially of Italian origin, and it is said in a biographical note on him that "Holland's brother John, who also spent much time in Rome, acquired further antique fragments for him": see David Watkin "Holland, Henry" in Oxford Dictionary of National Biography (2004, online ed Sep 2013, accessed 19 Aug 2015); Stroud 1966, who states at 19 that Henry's brother, John, was borne in 1757, at 29 n 2 (incorrectly) that he became "an Admiralty High Court Judge", and at 147 that John acquired some antique pieces for Henry.

143 He had married her in Nov 1790 at St George's Church, Hanover Sq: see Ed Pope History, sv "Holland John" available at http://www.edpopehistory.co.uk (accessed 17 Aug 2015). 
Judge on prizes in their nature doubtful". Holland, she continued, "seemed surprized that anyone should [have] looked for him with anxiety as he had supposed he should be quite an idle man, the more he has to do the better". ${ }^{144}$

Holland's salary as Admiralty judge was fixed at $£ 600$ per annum. ${ }^{145}$ In addition, he was entitled to supplement his salary by what was called the "fees of office", a share in all fines levied and penalties imposed by his Court, an entitlement comparable at the time to that of the fiscal of the Court of Justice. However, the basic salary too had to be paid out of the penalties, fines and forfeitures generated in the colony by the seizure of enemy property and contraband, as had been envisaged in the Order-inCouncil establishing his Court. Although London clearly thought that there would be sufficient funds from that source, ${ }^{146}$ Holland soon complained about his salary. That gave rise to slightly acrimonious correspondence between himself and the Governor and to repercussions between the latter and London.

On 22 February 1798, Governor Macartney wrote to Secretary of State Henry Dundas in London ${ }^{147}$ to inform him that the funds generated locally would fall far short of providing Holland with his approved salary and would necessitate the deficiency being paid out by the Treasury, as envisaged in his appointment, something that would subject the Judge "to very great inconvenience, uncertainty, and delay". Macartney suggested, though, that, unless it be decided to pay it fully from the Treasury, it would be simpler to pay his whole salary out of the general local revenue (rather than supplementing it by way of a percentage of the "penalties and seizures"), especially as he did not envisage "that so many seizures are likely to occur in future as ... would produce the $£ 600$ intended as a provision for the Judge of the Court of Vice Admiralty's salary".

In March 1798, no doubt in response to the salary issue, Governor Macartney, in formally re-establishing the post office, also appointed "John Holland Esquire ... to superintend the duties thereof as Postmaster-General". ${ }^{148}$ His office was in the

144 Barnard Letters: 99 (letter 3 Feb 1798 to secretary of war, Henry Dundas in London).

145 By comparison, at the time the President of the Court of Justice (Olaff de Wet) received the equivalent of Rds5 000 ( $£ 1000$ ) p/a, and its other members between Rds1 000 ( $£ 200)$ and Rds500 (£100): see, further, n 154 infra. The salaries of officials sent out from England were in pounds rather than in rixdollars: Freund 1989: 345.

146 See Theal $R C C$ vol 2: 290 (letter Henry Dundas to Governor Macartney, 28 Jun 1797, referred to in a letter by Macartney to Holland, 13 Oct 1798, in which it was stated that "in the event of any surplus of fees" in the Vice-Admiralty Court, the Judge had to account for it to the local "fee fund").

147 See Theal $R C C$ vol 2: 240-242

148 See the Proclamation on the Re-establishment of the Post-Office, 6 Mar 1798 (in Kaapse Plakkaatboek vol 5: 128-129). The establishment of an official postal service - for overseas mail only - at the Cape was provided for in Sep 1789 with a "post comptoir" (open from 09:00 to 10:00 daily) in the Leerdam bastion in the Castle (where it remained until 1809). The envisaged service only came into operation in Dec 1791 when Adriaan Vincent Bergh was appointed the first postmaster. Shortly after the First British Occupation, the post office resumed its service, with Bergh initially remaining in his post at a salary of $£ 400$ per annum, until the formal reorganisation in 1798. See, further, "The rise of the General Post Office in Cape Town 1792-1910" available at http://www.sahistory.org.za (accessed 3 Feb 2017); Jurgens 1943: 11-13; Goldblatt 1984: 21-27; Moree 1998: 140-141, 246. 
Castle, where two clerks assisted him. The position brought him an annual revenue of around $£ 400,{ }^{149}$ the entitlement to which ran from the beginning of 1797 , because, as Macartney explained to London, at that time "his appointment of Judge of the ViceAdmiralty Court commenced and he was ready to have proceeded to his destination, but was only prevented by a disappointment in the ship on board of which he had hoped to take his passage". ${ }^{150}$

In October 1798, the matter of Holland's salary came up again. Macartney wrote to him, ${ }^{151}$ enquiring whether there was any surplus of fees generated by the Court (and which had to be accounted for and paid over to the Receiver General). Holland replied ${ }^{152}$ that "no Fees to the Judge have yet been received for business done by virtue of that Commission [the one by which he was appointed], but they shall regularly be accounted for as they are". He continued by pointing out that in his view there was "a solid distinction on the question of Fees" between those received for business done in the Instance Court, in respect of which there was a restriction in the standing Commission appointing him as Judge of the Vice-Admiralty Court on his entitlement so that a surplus should be paid over, and those received for business done in the Prize Court, by virtue of a separate Prize Commission of appointment in which there was no such restriction and hence no need for any accounting. In fact, he had obtained "a professional opinion" on the matter from no less eminent an Admiralty lawyer than Sir William Scott. ${ }^{153}$ Based on that opinion, Holland continued, "I have considered the Fees received in Prize Causes as applicable to my own use". He concluded by observing "that an increase of Salary, even tho' it were inferior to the Emolument arising from Fees, would be far more agreeable ... than a continuance of the receipt of them, as it excludes the possibility of a sinister motive being imputable to an Officer in my situation acting in the discharge of his Public duty". Macartney then informed Dundas of this correspondence. ${ }^{154}$

149 See Giliomee 1975: 99; Boucher \& Penn 1992: 167 n 77.

150 See Boucher \& Penn 1992: 200, reproducing a private letter by Macartney to Dundas, 3 Mar 1797.

151 Theal $R C C$ vol 2: 290 (letter Macartney to Holland, 13 Oct 1798).

152 Idem 291-293 (letter Holland to Macartney, 14 Oct 1798).

153 Scott's opinion, dated 1 Nov 1797 (attached to Holland's letter to Macartney), was that if there was no limitation on the entitlement to fees in Holland's "Prize Commission", he was not restrained from taking fees as he was by the limitation occurring in his "standing Commission as Judge of the Admiralty", which had to be understood as referring to "the Ordinary business" of his office as Judge and not "the Extraordinary business" as Judge in the (Vice-Admiralty Court sitting as) Prize Court, a business "extraordinary both in its nature and its magnitude" and one that is "usually provided for by an increase in salary or by a receipt of fees". However, Scott suggested that Holland should clarify the matter with the Lords of the Admiralty, which Holland did on 16 Mar 1798. William Scott (1745-1836), the brother of John Scott, Lord Eldon (Lord Chancellor 18011806 and 1807-1827), was King's Advocate 1788-1789, Judge of the Admiralty Court 1798-1828, knighted in 1788, and created Lord Stowell in 1821. On Scott, see Bourguignon 1987.

154 See Theal $R C C$ vol 2: 293-295 (letter 15 Oct 1798, attaching Holland's letter and Scott's opinion; the letter also contains a list of the principal officers of government in the colony with their salaries: Holland received $£ 400$ as Postmaster General and $£ 600$ (Rds3 000) as Judge of the ViceAdmiralty Court; the salary of Olaff Wet, President of the Court of Justice, was Rds5 000 ( $£ 1000$ ) and members of that Court received Rds1 000 (£200) each; the latter salaries were increased by Rds500 in Dec 1798 for those members appointed to superintend the issue of new paper money at the Cape. See, also, Theal RCC vol 2: 309-311 (letter War Office to Macartney, 15 Dec 1798). 
Although instructions in 1797 had stopped the practice of adding to the fixed salaries of colonial officials with fees or other similar additional supplements, ${ }^{155}$ that did not apply to Holland as Judge of the Vice-Admiralty Court, "who has received permission to take the usual fees as part of the salary of that Office" ${ }^{156}$ Further developments in 1802 caused Holland to be restricted to his fixed salary and to lose the traditional additions to his salary in the form of fees of his office derived from receiving a portion of all fees levied and fines imposed by his Court. ${ }^{157}$

Apart from the issue of his salary, Holland also took up the quill to write to Henry Dundas about other matters coming to his attention as Judge of the ViceAdmiralty Court.

In January 1799 he raised observations "made in a leisure hour and solely with a view to public good" on the issue of the protection of the trade interests of the East India Company and the apparent lack of authority of the Vice-Admiralty Court under applicable legislation to act against infringements of its monopoly by British citizens operating under the guise of neutral ships. ${ }^{158}$

A short while later, in April of the same year, he wrote about what he termed a "difference of sentiment" between himself and the Governor on the matter of the

155 See Theal $R C C$ vol 2: 35 (letter War Office to Macartney, 7 Jan 1797, informing that fees and perquisites received by public offices in the colony should not belong to the person(s) employed in those offices, but should be appropriated to the payment of the salaries of such appointees). Thus, fixed salaries could no longer be supplemented with fees: see Freund 1989: 345, pointing out that in 1797 Britain raised official salaries and created some where none had existed before, and also, in an attempt to curb corruption, suppressed certain perquisites which formerly had been the principal income of officials.

156 See Theal $R C C$ vol 2: 433-434 (letter War Office to Governor Yonge, 30 May 1799) concerning the appropriation of fees and perquisites, and inclosing instructions issued to his predecessor which had to be strictly adhered to (ie no supplementation of salaries by fees) "except in the single instance of the Judge of the Vice Admiralty Court". See, further, Giliomee 1975: 99 n 57, who points out that after 1797 the only exceptions were the fiscal and the Admiralty judge, who also received a portion of fines levied in his Court.

157 In 1802 Holland was placed on the civil pay list and was paid directly by the paymaster: De Villiers 1967: 175; Giliomee 1975: 99

158 See Theal $R C C$ vol 2: 347-348 (letter Holland to Henry Dundas, 29 Jan 1799) and again n 50 in Part 1. He explained that a considerable portion, if not most, of all neutral ships (especially Danish ones) sailing to or from the East Indies that had entered, or had been captured and brought to, the Cape, had been commanded by Englishmen or Irishmen who had become naturalised Danes. As neutrals, they visited and traded from different settlements, including British ones and ones belonging to friendly nations. It was generally known that the greatest part of such ships and cargoes were, in fact, owned by British subjects residing in Britain or India and were merely coloured neutral. Their fraudulent trade (in monopoly goods) impacted on the Company's revenue. The problem was that, "[a]s the law stands at present (unless any act or regulation has taken place since I left England)", if a ship disguised as neutral was captured during a war on suspicion of having enemy property on board and was then brought into the Cape, but later appeared upon investigation to be the property of a British or Indian resident, and even though perhaps commandeered by a British subject or actually proved to be trading to or from India in violation of s 129 of the East India Co Act, 1792 (33 Geo III c 52), "yet the Vice Admiralty Court here would be bound to release such ship and cargo, having no power under the above Act to confiscate any property or to take any cognizance whatever of offences committed against it" (as it would if it were an enemy ship or a neutral ship carrying contraband). Holland therefore later raised the possibility "to invest the Vice Admiralty Court here with the same powers possessed by those in the East Indies and America" so as to enable it to deal with "the illicit encroachments on the Company's Trade". See, also, Theal RCC vol 2: 427-428 (letter Holland to Henry Dundas, 20 May 1799, in which Holland stated that his earlier sentiments had been fully justified by the case 
Angelique which had been brought before his Court as a prize for adjudication, but where the government had "opposed the execution of the decrees of the Vice Admiralty Court", requiring the landing and sale of her cargo pending litigation to prevent its perishment. ${ }^{159}$

As to details of Holland's residence at the Cape, one is largely and fortuitously reliant on Lady Anne Barnard. ${ }^{160}$ She and her husband, Colonial Secretary Andrew Barnard, frequently dined with Mr Hollande (as she tends to refer to him) and his wife. ${ }^{161}$ She described him as "a man who was pleasant, almost handsome, though somewhat of the old Beau, rather clever but of a spirit too encroaching for influence", ${ }^{162}$ and as an "upright judge", kindly, ${ }^{163}$ but in "bad health" 164 and frequently argumentative because of asthma. ${ }^{165} \mathrm{I}$ can also attest that Judge Holland had a particularly bad and illegible handwriting. ${ }^{166}$

of the Eliza, an American vessel that had put briefly into the Cape for refreshments on an apparent voyage from Madras to New York; despite the absence of evidence in the colony, Holland himself had little doubt that the whole or greater part of her cargo, if not the ship herself, belonged to British subjects).

159 Theal RCC vol 2: 408-409 (letter Holland to Henry Dundas, 5 April 1799). See, again, at n 60f in Part 1.

160 On Lady Anne, see the wonderful recent biography by Stephen Taylor Defiance. The Life and Choices of Lady Anne Barnard (London, 2016).

161 There are several entries in her Diaries referring to dinner at the Hollands or to their coming over for dinner at the Barnards. The dinners were enhanced by local wines. She recounts (Barnard Diaries vol 1: 102-103, Sun 13 Apr 1799) that they went to Little Constantia - the owner of Constantia next door not being at home - which had some equally good (at least the white) wine, and that there the Barnards and the Hollands bought $1 / 2$ aum $(1$ aum $=1451)$ of wine! Later that day, when the Hollands and others dined with the Barnards, the food was, to her sorrow, ill prepared by the servants without Lady Anne's earlier supervision, for, as she wrote, "a bad dinner is not an unimportant matter to Mr Holland".

162 Barnard Journals: 287.

163 Barnard Diaries vol 2: 105 (Apr 1800) tells what she calls "a homely little" tale: Holland had as Judge of the Vice-Admiralty Court condemned slaves to be prize property on the evidence of a "Black boy", who, on second examination of his evidence, prevaricated so much that Holland dismissed him, saying "your former evidence I see contains all you have to say, so you may go".

164 Barnard Letters: 176 (letter Sep 1798), writing that "we all like Mr Holland very much - I believe he is reckond by impartial people (which of course the partys seldom are) an upright judge - he has bad health, but I think he is a good humoured, agreeable man".

165 Barnard Diaries vol 1: 14 (9 Jan 1799), writing that when the Hollands came over for dinner, she observed that Mrs Holland has "of late been disposed to be rather more agreeable and companionable, he is always so, if his Health permit"; Barnard Diaries vol 1: 253 (25 Aug 7199), writing that when they dined at the Hollands with a number of other guests, the cold weather and heavy rains "agree ill with Mr Hollands asthma, he gasps and lives by aether". During the dinner, Holland "could not have resisted combatting [one of the guest's arguments] with legal ability, but he was not up to it"; Barnard Diaries vol 1: 315 (29 Oct 1799), describing dinner at the Pringles with the Hollands, where he had "a droll miff" with another (lady) guest "on the subject of cold pudding": there had been a very good plumb pudding at dinner and someone said it would be very good cold; Holland was "wheezing with the asthma \& not much thinking what he was saying", as a result of which the lady guest left weeping; Barnard Diaries vol 1: 318 (4 Nov 1799), referring to Holland being agitated to such an extent by another guest's deceitful words as to "cut off six months enjoyment to his wheezing tenure of life"; Barnard Diaries vol 2: 240-241 (28 Sep 1800), describing dinner with the Hollands, "he asthmatic". Stroud 1966: 29 n 2 states that John Holland and his wife "lived mostly abroad because of his health" and at 147 that John "spent a great deal of time in Italy on account of his health" where he had many royal and artistic acquaintances.

166 Especially in his Court's correspondence in CA, BO 35; however, notary Rouviere's (see at n 207 infra) hand was, if at all possible, even worse (see, eg, CA, BO 35, 175-188). 
Lady Anne's favourable opinion of Judge Holland was despite evidence of a fairly uneasy relationship between Holland and her husband's boss, the Governor, as well as other senior officials. ${ }^{167} \mathrm{~A}$ little more than a year after his arrival she wrote ${ }^{168}$ that she was beginning "to like him better than almost any man in the Cape, he is frank, says what he feels, without management or without fear of its being repeated \& never shall it be repeated ... he really does not appear to me to be a bit wrong in any of the disputes or rather misunderstandings between him \& Genl Dundas or $\mathrm{Mr}$ Ross". But whatever the relationship between Holland and the other British officials, he, and other members of his Court, were nevertheless clearly loyal to the Crown and the British cause. ${ }^{169}$

Although Lady Anne Barnard thought that Holland sought to influence her husband - she at one time feared that her husband was on occasion somewhat swayed by Holland, "who is not a temperate adviser" 170 - she realised that there was no danger of that "as he saw it too". ${ }^{171}$

But while Lady Anne Barnard was quite well disposed towards the Judge, she was less taken by his wife, describing her, at least initially, as less agreeable and companionable than her husband, ${ }^{172}$ with manners that left much to be desired. ${ }^{173}$ Although she later somewhat revised her opinion, ${ }^{174}$ this was not to last, mainly

167 See, eg, the entries for 1 Mar and 10 Mar 1799 (Barnard Diaries vol 1: 57, 69), both cases where the Hollands had come over for dinner and where there was evidence of altercations between the Judge and Gen Francis Dundas and of his uneasy relationship with the latter.

168 Barnard Diaries vol 1: 81-82 (22 Mar 1799).

169 See Theal $R C C$ vol 2: 333-334 (letter from various British colonial officials at the Cape to Gen Dundas, 5 Jan 1799, expressing their support for the war effort "at home" and offering their services to defend "this valuable Colony" against "a host of Foreign and domestic Enemies"; apart from John Holland, it was signed by other members of the Court, namely Thomas Wittenoon(m), George Rex, Peter Mosse, William Menzies and William Sturgis, all of whom we will encounter shortly).

170 Barnard Diaries vol 1: 204 (27 Jul 1799).

171 Barnard Journals: 287.

172 See Barnard Diaries vol 1: 13 (9 Jan 1799), describing Mrs Holland as of late disposed to be rather more agreeable and companionable; idem: 30 (27-30 Jan 1799), stating that she has hopes for Mrs Holland as she was beginning to act rational.

173 Barnard Diaries vol 2: 209-210 (Aug 1800), referring to a dinner party at which the tiresome comte Franchecoeur sang - "like a cow lowing to be sure, \& so affectedly that it was ridiculous enough" - and messrs Holland and Blake began laughing "illbredly", so that "the evening did not pass pleasantly"; Barnard Diaries vol 2: 257 (Oct 1800), describing an attendance at a sale of dresses of all kinds, including of the kind in which Marie Antoinette had been beheaded - "robe a La victime"; Mrs Holland purchased one as she "loves a bit of any thing new, the Cape was quite convenient she said for being guillotined, it rose up so High - in order to fall down so low! But as she did not intend to have the ax around her head she had trimd it with point lace which she had taken from a cap, some boxes of wc were also sold, vastly cheap".

174 Barnard Diaries vol 1: 94-95 (1, 2 Apr 1799), stating that Mrs Holland has improved "certainly on closer acquaintance, the fine lady going off and the reasonable little woman I hope by degrees coming in its place". But then, later (Barnard Diaries vol 2: 240-241 (28 Sep 1800), she described her as being "an old miss and will be one all her life". 
because of Mrs Holland's rather public infatuation with Major Peter Abercrombie, ${ }^{175}$ which caused the Judge some embarrassment ${ }^{176}$ and raised the suspicion of his having been made a cuckold of. This is supported, if not quite proved, by another incident involving the Hollands' French cook. ${ }^{177}$

175 Barnard Diaries vol 1: 210-211 (1 Aug 1799), describing how, at her ball, the company flirted, danced, ate, drank and, she was sorry to say, "one foolish woman wept - how can Mrs H[olland] become so very silly about a creature so contemptible as Major A[bercrombie]! one who asks but to show forth his power over this foolish old girl"; Barnard Diaries vol 1: 282 (26 Sep 1799), telling of an incident at a shop where Mrs Hogan had walked with Mrs Holland and her friend, the elder Mrs Losper (Laubscher?). When it was mentioned that Maj Abercrombie had arrived, Mrs Holland said nothing, but darted downstairs and pelted home as fast as she could, leaving Mrs Hogan without word of apology; Barnard Diaries vol 1: 283 (28 Sep 1799), describing that she visited "the poor foolish Holland who we found sitting in her chair in the attitude of thinking \& expecting ... Major Ab, who followed us in; and very (exaggeratedly so) slight bow she made to him showed many things all very silly". Abercrombie later married the younger Laubscher daughter, Kaatje (Catharine Cornelia), but Mrs Holland's infatuation continued: Barnard Diaries vol 1: 311 (Oct 1799), writing that she saw a surprising thing: "a deluge of tears from the large blew eyes of Mrs Holland, Major Abercrombie by her side \& his wife at the far end of the table ... how foolish it is in that little woman not to close the connection now, married as he is from choice to another"; Barnard Diaries vol 1: 315 (29 Oct 1799), describing dinner at the Pringles with the Hollands, and also with Maj Abercrombie, without his wife, and everyone being aware that Mrs Holland was "not cured"; Barnard Diaries vol 2: 47 (9 Feb 1800), describing how, on visiting, they found Mrs Holland in tears, Maj Abercrombie alone with her and Mr Holland sitting over a bottle with a gentleman in the Hall; she and the Major seemed so much disconcerted and so melancholy that the visit was cut short; on leaving, the Judge followed Lady Anne out, looked at his wife and with an appealing smile to Lady Anne shook his head in a way that she could see an uncle or father would do, but in a manner that did not seem to belong to a husband: how could he smile at tears so oddly bestowed, Lady Anne could not understand at all. Major Peter Abercrombie served at the Cape 1796-1802 and married Catherine Cornelia Laubscher in Nov 1799; she left with him when he went with his regiment to India, but returned as a widow in 1808: see Philip 1981:1.

176 Barnard Diaries vol 1:234 (13 Aug 1799), describing how, after Holland had made "some common place jest of soldiers being careless of their wives", Gen John Henry Fraser (commanding officer of the troops at the Cape in the absence of Gen Dundas, Aug-Dec 1799: Philip 1981: 133) took it personally and replied that he thought soldiers took very good care not only of their own wives, but also of the wives of civilians, and then applied it "in flat \& brutal terms to Mrs Holland and Major Abercrombie"; Lady Anne remarked that she thought "Mr H was hurt" by these remarks.

177 To her letter to Earl Macartney, dated 15 Feb 1800 (see Fairbridge 1924: 168-169), Lady Anne added "a bit of good jest" as an addendum. It concerned the Hollands' good French cook, a prisoner of war from the Battery, who was returned there. The reason, the Judge later explained, was because the cook was mad. But Mrs Holland later told Lady Anne that the poor man was certainly not so very mad, but mighty odd and tiresome. She explained that he had asked to be paid off and to be returned to prison because, so he told her, he loved her; he later sent her a letter, declaring his affection. "The poor cook's secret could no longer be concealed", Lady Anne continued, "but what is very provoking, everyone thinks him madder than Mrs Holland". Back in prison, the cook would go to no other employment the Judge would find him, calling loudly for death to end his sorrows and imploring the Judge's pardon on his knees for the presumption of his sentiments. But then Lady Anne concluded: "N. B.- Tho I tell this gayly, don't conceive the slightest ridicule or reflection on Mrs Holland by it." See, also, Barnard Diaries vol 2: 33-34 (Feb 1800 ), writing that her husband did not believe that any man would be so mad as to fall in love "with this poor pretty little woman unless he had been a little invited" and that Mrs Holland had certainly sighed when Lady Anne referred to "poor Cookie". 
At one stage, the Hollands resided outside of town, some ten minutes' walk from the centre. They were no doubt quite disappointed that there was not room for them in the Castle, as there was for the Barnards. ${ }^{178}$ In November 1800, Holland advertised the property, proposing to exchange it "on equitable terms" for a house in Cape Town or to sell it by private contract. ${ }^{179}$ An arrangement was then made with one Carel Bester, by which the latter bought Holland's property and in exchange for which Holland bought Bester's property in town. ${ }^{180}$ This house was situated at 47 Breede Street on the corner with Hout Street, between the properties of messrs Hermans and Hofmeyer, ${ }^{181}$ and close to the Barnards. ${ }^{182}$ Ironically, it seems, the house Holland bought may have been one he had lived in before. ${ }^{183}$

But the Hollands' sojourn at the Cape was not to last. With the approaching return of the Cape to the Dutch and the resulting closure of the Vice-Admiralty Court, Judge Holland and his wife departed from the colony in September 1802. As we will see, most of his colleagues, with a few notable exceptions, ${ }^{184}$ left the Cape

178 See Fairbridge 1924: 225 (letter Lady Anne Barnard to Earl Macartney, 18 Oct 1800).

179 See Cape Town Gazette of 10 Nov and 13 Dec 1800, describing the house as "situate in the neighbourhood" of Cape Town, previously belonging to Mr Casper Loos and now the property of, and occupied by, Holland. It was advertised for sale by public auction, together with "several slaves, wagons, carts and sundry garden and husbandry utensils".

180 See CA, NCD 1/35/823 for the notarial protocol, dated 7 May 1801, by which Holland sold to "Pester" (sic: Bester) for Rds50 000 the property which had formerly belonged to, and which he had bought from, Johan Caper Loos, and by which Pester sold him his house in town for Rds80 000.

181 For the notarial protocol, dated 24 Jun 1801, pertaining to the obligation on Holland's part to pay the outstanding amount of some Rds30 000 to Bester, to be paid over period of a year, see CA, NCD 1/28/790 (1801), in Dutch together with a translation into English. See, also, Cape Town Gazette of 23 and 30 May 1801, advertising a sale in the garden of the house formerly belonging to Carel Bester and now to Holland. This exchange of properties caused Holland to send off a memorial, dated 3 Jul 1801, to Governor Dundas concerning the apportionment of transfer duties, which was allowed, duty being payable on the difference between the values of the two properties: see CA, BO 121/34/1 (1801).

182 Barnard Diaries vol 2: 49 (10 Feb 1800), describing how, after dinner, the Barnards "walked up to see Mr Hollands house wc is behind this - I did not much like it [it had "a very circumscribed view, sadly enclosed"] but as he has paid about 30,000 for it \& has still much to do to render it convenient I did not say so". She expressed a similar sentiment when she visited it on 10 Mar 1800, after some improvements had been made: see Barnard Diaries vol 2: 69: "I did not like it so well as I did before it was fitted up with its bare clean walls, the paper was ugly and the roof painted so dark as to lose the chearful look it had before."

183 See Fairbridge 1924: 279-280 (letter Lady Anne Barnard to Earl Macartney, 27 May 1801, recounting that Holland had sold his country house and came to live in town again, "in the same house he was in before, which by a variety of manoeuvres now costs him 80000 dollars").

184 These being Rex, who retired and went farming at Knysna, Rowles and Pontardent, who left but later returned to the Cape, and Ziervogel, who, being a local recruit, remained. More about them shortly. 
around the same time. The house he had acquired was probably sold, as were the slaves he, like so many other Cape Town residents, possessed. ${ }^{185}$

The Hollands returned to England, but a little time later John Holland was appointed and took up the position of Chief Justice ${ }^{186}$ of the Vice-Admiralty Court in Jamaica. ${ }^{187}$ The Vice-Admiralty Court there, sitting either in Kingston or in Spanish Town, was the oldest such court in the British colonies, having been established in 1662. ${ }^{188}$ Like colonial Admiralty courts elsewhere, it heard both ordinary, Instance causes and, in time of war, Prize causes. ${ }^{189}$

The Hollands arrived on Jamaica in late $1803 .{ }^{190}$ As with the Cape, the main source of information about their stay on the island is the journal of a diarist, this time Lady Maria Nugent, the wife of the Governor, George Nugent. ${ }^{191}$

185 See, eg, CA, NCD 1/39/358 (1798) for a notarial protocol concerning the transfer by Adv Peter Mosse (see at n 248 infra) of the slave "Spasie van de Caab" to Holland in Dec 1798; CA, NCD 1/15/1400 and 1404 (1801) for a notarial protocol dated 21 Jan 1801, by which Holland gave a special power of attorney to Jan Bernhard Hoffman regarding a dispute in the Court of Justice with Jean Charles de la Harpe over the sale of a slave.

186 Chief justice rather than merely judge, presumably because there were other Admiralty judges in other locations on the island.

187 See The New Jamaica Almanack and Register ... for ... 1801 (Kingston, 1801) at 109. An amount of $£ 473$ 8s 1d was budgeted for Holland (as also for the chief justices of the Vice-Admiralty courts at the Bahamas and Barbados) from the consolidated fund for the year ending Jan 1804 with a future annual charge of $£ 2000$ p/a, probably his salary: see House of Commons Parliamentary Papers Accounts Respecting the Public Expenditure of Great Britain, for the Year Ended 5 January, 1804 (HCPP 1803-1804 (vol 23)) at 11; in idem Accounts Respecting the Public Income of Great Britain, for the Year Ended 5 January, 1804, at 87 there is mention of "Henry [sic] Holland, Esq, Chief Justice of the Admiralty Court in the Island of Jamaica, per Act 43 Geo III". The following year, during which he died, the amount was $£ 3281 \mathrm{~s} 9 \mathrm{~d}$, maybe the part of his salary due on his death: see Parliamentary Debates vol 5: 15 May to 12 Jul 1805, "Account of the Charges upon the Consolidated Fund, in the year ending 5th Jan 1805" at ccxxxi.

188 See Crump 1931: 91-105; see, also, Leach 1960; Butterfield 1938: 97, distinguishing between the records of the Vice-Admiralty Court and those of "the special courts of oyer and terminer for the jurisdiction of the admiralty of the island of Jamaica, which tried ... felonies committed on the high seas, piracies, and murder". As Chief Justice of the Vice-Admiralty Court, Holland was also a member of the Court of Admiralty Sessions, the name for the Piracy Court there.

189 And like Vice-Admiralty courts elsewhere, the Jamaican one was relatively quiet outside of war. One of Holland's better-known predecessors, Edward Long (1734-1813), although reviled today (see Seth 2014), but nevertheless remembered as an historian and the author of The History of Jamaica (published in 3 vols in London in 1774), wrote (in vol 1 at 78) that "in time of peace, it is a court of no profit, and of very little business". On Long, see also Bridges 1828, vol 1: 26; SP 1933.

190 His immediate predecessor in 1801 was George Cuthbert: see The New Jamaica Almanack and Register ... for ... 1801 (Kingston, 1801): 109. The well-known naval historian, William James, was a proctor in Holland's Vice-Admiralty Court in 1803: see AB Sainsbury "Duckworth, Sir John Thomas" in Oxford Dictionary of National Biography (2004, online ed Jan 2009, accessed 19 Aug 2015).

191 On Lady Nugent (1770/1-1834), see Rosemary Cargill Raza "Nugent [née Skinner], Maria" in Oxford Dictionary of National Biography (2004, online ed 2009, accessed 19 Aug 2015). Her diary was published in 1966, and reprinted in 2004: see Wright 2004. George Nugent (1757-1849) was appointed Lieutenant Governor of Jamaica in 1801, where he remained until 1806. Lady Nugent returned to England in 1805 for the sake of their children's health. 
On 29 November 1803 she wrote that she had received several high-ranking visitors, "[a]mongst them was Mr Holland, just arrived as judge of the Admiralty". With him was his wife, formerly a Miss Eden, and, Lady Maria hoped, she would "be an acquisition to our society". The Hollands stayed for dinner and Lady Maria wrote that she and her husband "both like Mr Holland's manner much". ${ }^{192}$

As at the Cape, Holland proved a rather sociable dinner companion. A few days later, on 3 December, Lady Maria wrote that at a large dinner party "Mr Holland drank so many bumpers of claret, that he got into high spirits, and gave up, in the Court of Admiralty, every point of which he had been so tenacious in the morning". ${ }^{193}$

Sadly, Holland's tenure was cut short a few weeks later. On 12 January 1804, Lady Maria diarised the news of Holland's sudden death, "which shocked us very much". ${ }^{194}$ He was buried in the St Andrew's Parish Church on the island, where the inscription on the commemorative white marble mural reads:

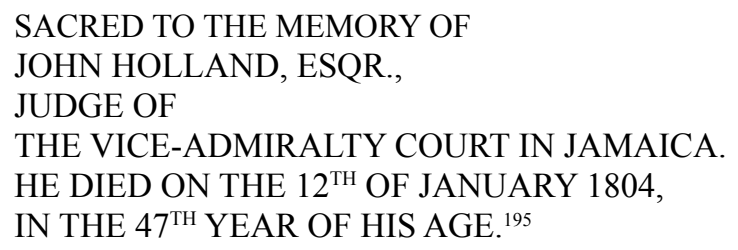

Holland's quickly appointed successor ${ }^{196}$ became one of the most illustrious of all colonial Vice-Admiralty judges: he was Henry John Hinchliffe, Judge of the Jamaican Vice-Admiralty Court from 1804 to 1812 and again from 1814 to 1818 . He is today remembered, in appropriate circles, as the author of Some Rules of Practice for the Vice-Admiralty Court of Jamaica Established [the rules] January, 5 1805, which was published in London in 1813. ${ }^{197}$

192 Wright 2004: 184.

193 Ibid.

194 Idem at 192. She had learned, from Adam Dolmage, the Court's Deputy Registrar, that Holland had "just fired a Gun at some Cattle which had broken into his garden when a blood Vessel burst $\&$ he died"; idem at $192 \mathrm{n} 1$.

195 See Lawrence-Archer 1875: 234; Wright 1966: 57.

196 Lady Maria (Wright 2004: 194) wrote on 20 Jan 1804 that Hinchliffe, who came over for breakfast, was "full of gratitude for his appointment of Judge of the Admiralty Court". Hinchliffe, a barrister without any practical experience in England, had come to Jamaica in 1801, "to seek his fortune"; he practiced there, and was "eloquent at the Bar, but not considered well versed in the law": see Wright 2004: 302 (Index of Persons).

197 Judge Hinchliffe was the brother of John Hinchliffe (1731-1794), bishop of Peterborough: see JJ Caudle "Hinchliffe, John" in Oxford Dictionary of National Biography (2004, online ed 2008, accessed 18 Sep 2015). For an American decision in which Hinchliffe and the Jamaican ViceAdmiralty Court featured prominently, see Yeaton v Fry 5 Cranch 335, 9 US 335 (US Dist Col, 1809), a case concerning a claim on a marine insurance policy. Evidence was submitted of the proceedings in and the decree of the Jamaican Court, ordering a sale to pay for the salvage of the insured ship. An issue arose as to the proper authentication of copies of the Vice-Admiralty Court's proceedings that had been admitted in evidence. Reference was made in the documents of authentication to Henry John Hinchliffe, Esq, as "judge and commissary of the court of vice- 
Mrs Catherine Holland, ${ }^{198}$ unsurprisingly true to the picture Lady Anne Barnard had painted of her, married one George Simpson in London in March 1805, a little more than a year after her husband's death. ${ }^{199}$

\section{Registrar John Harrison}

Second in importance after Judge Holland at the Cape Vice-Admiralty Court, but of whom almost nothing certain is unfortunately known, ${ }^{200}$ was John Harrison, who was appointed the Court's registrar (often also called its register) in January 1797.

The registrar, like the Court's marshal, was appointed by Letters Patent, under the Seal of the Admiralty, or by the Governor when there was no Admiralty appointment. The registrar was authorised to act by deputy, sharing the profits, or to act in person. As the keeper, in its registry, of the records of and created by the Court, the registrar attended the Court's sittings and was often present in the judge's chambers, drew up and signed Court documents, controlled the moneys received or expended by the Court, and taxed costs.

According to one genealogical source, ${ }^{201}$ John Harrison was born on 20 November 1757 in Stantonbury in England, and married Irene Pearce on 11 September 1787, a marriage which produced no children. Before being appointed as registrar of the Cape Vice-Admiralty Court, he apparently served in the Commission of Peace for the Liberty and Borough of St Albans, was then also an alderman from 1788, and twice the mayor of that borough in 1789 and again in $1796,{ }^{202}$ and, possibly, sometime one of the Commissioners for the Victualling of the Navy ${ }^{203}$ Whether Harrison ever

admiralty in the island of Jamaica". There is also evidence that in 1804 Hinchliffe publicly sat as Judge of the Vice-Admiralty Court in Jamaica and in that capacity condemned the insured vessel. In The Reward (1818) 2 Dods 265, 165 ER 1482 at 270, 1484, Hinchliffe is described in the following glowing terms by no less an Admiralty giant than Sir William Scott (see n 153 supra): "The judge of the Vice-Admiralty Court at Jamaica (a gentleman of very considerable talents, and of singular judgment in the exercise of his functions) seems to have been perfectly right in putting a check to this practice [of allowing certain exceptions to a legal prohibition]."

198 Who inherited from her husband in accordance with a will drawn up in London in Aug 1790 and proved on 2 May 1804 before the Prerogative Court of Canterbury (see NA, PROB 11/1408/145, 367). The will that Holland and his wife had had notarially drafted (in Dutch) in Cape Town on 15 Oct 1801 (see CA, NCD 1/7/616/1) - and in which Holland is described as "Judge van zijn Groot Britaniasche Majesteits vice admiraliteyts Hof hier ter plaatse" - apparently did not feature.

199 See Ed Pope History "Holland John" available at http://www.edpopehistory.co.uk (accessed 17 Aug 2015).

$200 C f$ his entry in Philip 1981: 167.

201 See "Harrison, John" available at http://www.clanmacfarlanegenealogy.info (accessed 17 Aug 2015); also www.stamplink.com/genealogy (accessed 26 Apr 2012).

202 See the "Table of Mayors for St Albans Rural \& City \& District Council", available at $h t t p: / / w w w$. stalbans.gov.uk (accessed 15 Oct 2015); Gibb 1890: 146, 147, 149-151.

203 On the victualling commissioners, of which there were seven, see, further, Knight 2008: 145, who lists as a member of the Victualling Board of Commissioners "John Harrison, 27 Mar 1799 - 22 Aug 1807: private secretary to Lord Spencer, 7 Feb 1800 - 29 Feb 1801"; see, also, Sainty 1975: 65,129 . These dates cast doubt on whether this was our registrar Harrison, or, if he was, whether he was then actually at the Cape. 
came to the Cape and, if so, when he left, is not clear ${ }^{204}$ and the date of his death is likewise uncertain. ${ }^{205}$

One possible explanation for the dearth of information on Harrison's activities at the Cape is that, as he was entitled to do, he performed his duties through a deputy, and that he never actually came to the Cape. If so - and the appointment of a deputy registrar gives credence to this possibility - he was certainly not the last of the Court's registrars to exercise his office in this manner. ${ }^{206}$

\section{Deputy registrar Rouviere}

BG Rouviere ${ }^{207}$ was the Vice-Admiralty Court's deputy registrar and is also listed as its actuary ${ }^{208}$ and later also as its examiner, although Rouviere and Judge Holland disagreed on what exactly his rights and duties in the latter capacity entailed. ${ }^{209}$

204 He is said to have subsequently been a director of the Royal Hospital (in the sense of "hospes") for Seamen at Greenwich: see http://www.clanmacfarlanegenealogy.info (accessed 17 Aug 2015) and also A Report of the Proceedings of ... and John Harrison Esq, Directors of the Royal Hospital for Seamen at Greenwich (London, c 1810), being a report on the visitation of the hospital's estates in the North in Aug-Oct 1805. However, two editions of A Description of the Royal Hospital for Seamen, at Greenwich, ... with a list of the Directors .... (London, 1797) at 55 and (London 1809) at 52 mention no Harrison as director at all.

$205 \mathrm{He}$ was alive, without issue, it is said, in 1809 (see http://www.clammacfarlanegenealogy.info, accessed 17 Aug 2015). There is a gravestone in the Somerset Rd Cemetery in Cape Town, inscribed "John Harrison. Died 15-04-1866" (see Genealogical Society of South Africa Alphabetical Guide to Gravestones in the Somerset Road Cemetery, Cape Town, Cape (1 ed 1993) unpaged), but this is probably not our man as that would have meant he was ninety years old when he died. There is a further suggestion that he died in Feb 1830: Gibb 1890: 181.

206 The sinecure office of William H Grey, registrar of the Cape Vice-Admiralty Court 1807-1817, was similarly exercised by deputies: see Van Niekerk 2015a: $157 \mathrm{n}$ 81, 175-176.

$207 \mathrm{He}$ is in local sources, such as the Cape Town Gazette, invariably referred to by his initials, mostly "BG", but also on occasion "BW". He should be distinguished from French-speaking Swiss immigrants to the Cape bearing the same surname, such as Jan Auguste Rouviere (c 17831852) and Jeremie Auguste Rouviere of Neuchatel: see Linder 1997: 162, 201-202.

208 See the African Court Calendar for 1801. See, also, NA, HCA 49/33-11/c, containing a letter dated 26 Nov 1800 from Governor Yonge to Rouviere concerning his appointment as registrar and actuary in the Vice-Admiralty Court; Barnard Diaries vol 2: 13 n 11.

209 See the African Court Calendar for 1802. See, also, NA, HCA 49/33-11/c, containing a letter dated 8 Dec 1800 from Rouviere to the local King's proctor and former deputy registrar Wittenoom (as to whom more at $\mathrm{n} 225 \mathrm{f}$ infra), referring to the difference of opinion between Rouviere and Holland about the former's right of examining witnesses. He asked Wittenoom's advice on the matter and specifically on whether it was part of a registrar's duty to examine witnesses, or whether the judge had the right to appoint an examiner when the registrar and his deputy thought it proper for them to take the examinations themselves. On 9 Dec, Wittenoom answered, expressing the view that the taking of examinations of witnesses formed part of the regular and established duties of the registrar of an Admiralty court. He pointed out that the appointment of an examiner in the High Court of Admiralty in London was motivated by the fact that the business there was too great to allow the deputy registrar consistently taking examinations himself in addition to his other duties. 
He was appointed as deputy registrar and actuary of the Vice-Admiralty Court in November 1800 in the place of Thomas Wittenoom. ${ }^{210}$ There are many notices in the Cape Town Gazette during the period from 1800 to 1802, placed by "BG Rouviere, actuary", acting on behalf of the Court's registry and on the order of its judge, giving notice of when the "regular" Court of Vice-Admiralty or, less frequently, the "special" Court of Vice-Admiralty would be held. ${ }^{211}$ There are also notices in his name involving the expenses of the Vice-Admiralty office, or calling for persons willing to supply the Court with government bills upon England to submit tenders to the registry as to the terms on which they were willing to do so. ${ }^{212}$

Rouviere was also appointed as registrar of the Piracy Court in March 1801 when the initially appointed one, George Rex, had to beg off because of his clashing duties as marshal of the Vice-Admiralty Court. ${ }^{213}$ In that capacity, Rouviere had some difficulty in getting the government to meet the Court's expenses. ${ }^{214}$

Lady Anne Barnard was sufficiently shocked to diarise that "Mr Rouverie", as she called him, had arrived at the Barnards uninvited during dinner on 1 May 1800, but the relationship was not, as a result, permanently strained, for on 19 October she invited him and others, including the Hollands, to spend a few days with them. ${ }^{215}$

What exactly Rouviere did when the Cape Vice-Admiralty Court was closed in 1803, is not known, but he - and Wittenoom - surfaced in Malta as proctors practising before the local Vice-Admiralty Court there from around $1810^{216}$ and

210 See Cape Town Gazette of 29 Nov 1800; Philip 1981: 469.

211 See, eg, Cape Town Gazette of 5 Sep 1801 for the first, and Cape Town Gazette of 2 Jul 1801 for the second. The "special" probably refers to extraordinary, unscheduled sittings of the Court and not to sessions of the Piracy Court.

212 See, eg, Cape Town Gazette of 8 Aug 1801.

213 See Brooks 1802: 45 where it is noted that the Court disposed of the attendance of Rex and that "Mr Brown George Rouviere, Notary Public, was appointed and sworn in as Register accordingly"; see again n 121 supra.

214 See CA, BO 122/78/1 (memorial dated 24 Dec 1801 from Rouviere to Governor Dundas concerning the considerable expenses incurred by him as registrar of the "Court of Piracy" in May of that year in the Chesterfield matter, which had been applied for, but was still not yet paid, placing him, Rouviere, in a "very unpleasant situation" as regards the "various pecuniary demands which are continually made upon [him]"; it is entered on the memorial that Dundas instructed that Rouviere be informed that his account could, for technical reasons, not be discharged at that time).

215 Barnard Diaries vol 2: 119, 266 (1 May 1800, 19 Oct 1800); Rouviere had been to dinner before, on 21 Jan 1800: idem at $13 \mathrm{n} 1$.

216 Rouviere and Wittenoom are mentioned as two of the four practising proctors in the Maltese ViceAdmiralty Court in the 1811-1816 (there is no mention of proctors in the 1818-1820) issues of the Royal Kalendar, and Court and City Register for England, Scotland, Ireland, and the Colonies; see, also, the Gentleman's Magazine and Citizen's Almanack ... for 1815 at 156 . The Admiralty Judge in Malta at the time was Sir John Sewell (d 1833), holding a DCL from Oxford, who is buried in the Marylebone New Church near Baker St in London (see "Monuments in Marylebone New Church" available at $h t t p: / / w w w . s p e e l . m e . u k$ (accessed 10 Feb 2015)). The writer and lawyer, Sir John Stoddart (1773-1856), also an Oxford DCL, was King's Advocate there 1803-1807 and after then practising in Doctors' Commons, he returned to the island to become the Court's Judge 18261838: see GC Boase, rev Nilanjana Banerji "Stoddart, Sir John" Oxford Dictionary of National Biography (2004, online ed 2009, accessed 2 Oct 2015). 
possibly earlier ${ }^{217}$ On the island, Rouviere had a reputation as a prodigious imbiber of alcohol. ${ }^{218}$

The Maltese Vice-Admiralty Court was established in June $1803,{ }^{219}$ and is famous for its connection to the poet Samuel Taylor Coleridge ${ }^{220}$ and most infamous for the attacks of corruption, bribery and outrageous fees - detrimental to the interests of naval captors - levelled against it in, and outside, the British Parliament by the controversial naval officer, Thomas Cochrane, in 1810 and 1811. ${ }^{221}$

217 In Umbragio Obicini v Bligh (1832) 8 Bing 335, 131 ER 423, there is mention of a "Rouverie" acting as proctor for one of the litigants in the Vice-Admiralty Court on the island of Malta in Feb 1809. And in Hassam 1880: 10-12 there is recounted the arrest in Aug 1809 of an American vessel, captained by Jonathan Hassam, by a British naval vessel and of her being taken to Malta to be condemned by the Vice-Admiralty Court there as a prize. The Court's decree of restoration, dated 2 Oct 1809, has it that Rouviere appeared as proctor for the claimants.

218 This from the journal kept by Joseph Arnold (1782-1818, naturalist and naval surgeon: see Charles Bateson "Arnold, Joseph" in Australian Dictionary of Biography vol 1 (1966)), in which he wrote that on 7 Jan 1813 he attended a dinner in Malta at which some excellent alcoholic refreshments were served ("Claret, porter, Madeira, Beccaria porter, Burton ale, Hoch, \&c"). During dinner, the conversation turned to the Admiralty Court and he then mentions that "Mr Rouviere is a proctor, when he buys wine he sometimes orders 4 [... indecipherable] pipes - by himself ... he drinks a bottle of Burgundy or Champagne daily". The entry for 25 Jan 1813 refers to advice given on the treatment of the inflamed knee of a naval captain by "Mrs Rouviere wife of the rich proctor here". See "Joseph Arnold Journal", transcribed at http://acms.sl.nsw.go.au (accessed 20 Oct 2014).

219 See NA, WO 1/739; and, generally, Gregory 1996: 262-264, noting the (jurisdictional) conflict between the Vice-Admiralty Court and the Maltese civilian, criminal and commercial courts, the latter known as the Consolato di Mare.

220 Coleridge (1772-1834) - he of "Rime of the Ancient Mariner" (1798) fame - was acting public secretary on the island from May 1804 until Sep 1805, and in that capacity he fulfilled various legal and administrative functions, including organising the distribution of prize money and bounty and, allegedly, appearing in the Vice-Admiralty Court: see Hough \& Davis 2008. The military officer and part-time actor, Tomas Sheridan (1775-1817), son of the dramatist and politician Richard Brinsley Sheridan, had, in 1803, rejected the registrarship of the Maltese ViceAdmiralty Court before pursuing a military career; in 1812, ill health moved him to accept the post of colonial paymaster or treasurer at the Cape from 1813 until his death of consumption in 1817: see AKM "Sheridan, Thomas" in Dictionary of South African Biography vol 2: 661-662; Philip 1981: 378; A Norman Jeffares "Sheridan, Thomas [Tom]" in Oxford Dictionary of National Biography (2004, online ed 2008, accessed 15 Oct 2009).

221 For the speeches by Cochrane (1775-1860) in the House of Commons on 6 Jun and 18 Jul 1811 on the "Vice-Admiralty Court of Malta" and the "Conduct of the Vice Admiralty Court at Malta" respectively, see House of Commons Debates 6 Jun 1811 and 18 Jul 1811, vol 20 cc464-470 and cc1017-1027, available at http://hansard.millbanksystems.com (accessed 10 Feb 2015). Cochrane names several of the Court's officers - including Judge Sewell, who himself drew up the Court's scale of fees, the (sinecure) registrar John Locker and his deputy William Stevens, as well as the marshal John Jackson, who simultaneously, but illegally, acted and charged fees as a proctor - but makes no mention of either Rouviere or Wittenoom. See, further, on Cochrane and the Maltese Court, Lloyd 1947: 102-105; Cordingly 2008: 225-228. See, also, the polemic The Rape of the Table: or, Ten Honest Lawyers. A Poem in Two Parts. Comprising a Faithful Report of Some Extraordinary Proceedings in a Certain Court of Vice-Admiralty, by "A Gentleman well acquainted with the different members of the Court", published in Dublin in 1811. 
Only faint and inconclusive traces have been uncovered of what could be Rouviere's earlier ${ }^{222}$ and later ${ }^{223}$ life in England.

\section{Marshall George Rex}

George Rex was marshal of the Cape Vice-Admiralty Court from 1797 to $1802 .{ }^{224}$

\section{King's proctor, deputy registrar and practitioner Thomas Wittenoom}

One of the more interesting Admiralty lawyers at the Cape during the First British Occupation was Thomas Wittenoom. ${ }^{225} \mathrm{He}$ was born in London in 1759, the son of Cornelius Wittenoom - a vinegar maker of St Leonard, Shoreditch, himself the son of a Dutch immigrant - and his wife Elizabeth. ${ }^{226}$ Thomas qualified himself as a civil lawyer, and practised as a proctor in the Ecclesiastical and Admiralty courts in Doctors' Commons in London. ${ }^{227}$ For some time, Wittenoom practised in partnership

222 There is mention of a "George Brown Rouviere" as a notary public in the Ecclesiastical Courts in England in Apr 1800; see Lambeth Palace Library, item F I/U f 119.

223 See Journals of the House of Lords, vol 50, 1814 at 554, 605 and 718 where there is mention of Frances Henrietta Nash(?) and her husband "Brown George Rouviere" being involved in litigation in Barrettt v Bourke et al. See Q27/3/211 (1819) in the Hampshire Archives and Local Studies, which contains a document entitled "Justice Browne George Rouvière esq.; Property, Messuages and lands at Yateley". (This item is in the Archives' Records of Justices and Clerks of the Peace, etc, Hampshire Quarter Sessions (= Q), Justices of the Peace (= Q27), Certificates of qualifications of justices; messuage (or mesnage, a legal term for a dwelling house with outbuildings and land assigned to its use (= Q27/3)). See, also, Parliamentary Papers vol 43 "Accounts and Papers ... relating to Courts of Law ... etc" (1836) at 583: Justices of Peace (which is a list of persons appointed to act as such) where there is mention of "Browne George Rouviere" being appointed in the county of Southampton.

224 His career was considered in detail in Van Niekerk 2010.

225 Also spelt Wittenoon(e), Wittenome, or Wittemoon(e).

226 See NA, PROB 11/826/59 for Cornelius's will; and NA, PROB 11/1147/88 for that of Elizabeth Wittenoom, who is described as a widow of "Godliman Street, Doctors' Commons, London". They had five children: Cornelius, William Joseph, Thomas, Ann (Calvert), and Elizabeth (Caslon). Cornelius and William were appointed as executors of their mother's will, dated 5 Mar 1782. There is a record in the archives of the Court of Arches in the Lambert Palace Library (see Arches Aa 34, Arches Aa 83/37, and Arches Bb 95/23, available at http://archives.lambertpalacelibrary. org.uk (accessed 16 Sep 2015)) of litigation involving the brothers Cornelius and Thomas being sued by their sister Elizabeth concerning the legacy of their mother, Elizabeth, in 1788.

227 "Wittenoom, Mr Thomas Knight-rider-street" (which is where Doctors' Commons was situated) is listed in (1786) 4 - (1793) 11 Transactions of the Society ... for the Encouragement of Arts, Manufactures, and Commerce as one of the society's contributing members. The publication Civilian Trials for Adultery: or the History of Divorces, being Select Trials at Doctors Commons for Adultery, Cruelty, Fornication, Impotency, etc vol 6 (1780, London) at 58, mentions, in the case of Edward Payne v Sarah Payne, 15 May 1776, a "Mr Thomas Wittenoom, of Doctors Commons" as having proved the marriage of the parties involved. His petition in 1782 for admission as a proctor in the Court of Arches is in its archive in the Lambert Palace Library (Arches Kkk 4/33, Arches Kkk 16/39; and see, also, VB 1/11/319) as is his admission as a public notary in Sep 1780 (F I/P f 168V). 
with Philip (de) Crespigny and his son ${ }^{228}$ until a dispute between them ended in litigation and the termination of the partnership in $1792 .{ }^{229}$

Thomas Wittenoom arrived at the Cape in February 1798, on the same ship as Judge Holland ${ }^{230}$ and, as a proctor entitled to practise in the Vice-Admiralty Court, he was at first appointed as the registrar and actuary of the Court. In that capacity he dispensed - was compelled to dispense - with the services of proctor Pontardent after he, because of his involvement in the Jessup affair, ${ }^{231}$ had been banished from the colony.

There are several archival items giving further information on Wittenoom's tenure and duties as registrar, ${ }^{232}$ and on correspondence to and from him in his official

228 See item VB 1/12/230 in the Lambert Palace Library, noting Wittenoom and Crespigny as practising as partners in 1790. Philip Charles Crespigny (probably the son, 1765-1851, the father having died in 1803) is mentioned as a proctor having an office in Doctors' Commons in 1809 Royal Kalendar, or, ... Annual Register for England, Scotland, Ireland, and America for ... 1810 at 275, and as a proctor in the 1810 British Imperial Calendar for 1811 at 229, which also mentions Wittenoom. Several Crespignys, of Huguenot immigrant stock, were civilian lawyers in England: grandfather Philip Champion (1704-1765) was a proctor in the Ecclesiastical and Admiralty courts and marshal of the High Court of Admiralty 1733-1745; father Philip Champion (17381803) was an advocate in Doctors' Commons in 1759, King's Proctor 1768-1784, and a member of Parliament 1774-1775 and 1780-1790. See Namier \& Brooke 1964: 275; Anne Young "Philip Champion de Crespigny", available at http://ayfamilyhistory.blogspot.co.za (accessed 21 Sep 2015).

229 See Crespigny v Wittenoom \& Another (1792) 4 TR 790, 100 ER 1304, which involved an agreement between Wittenoom, Crespigny snr, and his son Crespigny jnr, dated 1788. In terms of it, the parties had agreed that the business of the co-partnership as proctors would be carried on by them in the name of Wittenoom only, until Crespigny jnr should be admitted as a proctor, after which it would be carried on in both their names with Crespigny jnr becoming a partner in equal degree with Wittenoom. When Crespigny snr wanted to quit and give up the business, they agreed that the other two would pay him the annual sum of $£ 400$ during his life, by quarterly payments, and also a further sum of $£ 37110$ s every three months during the joint lives of himself and Mary Green, the widow of one J Green who was a former partner of Crespigny snr. The latter now sued the other two for breach of their agreement by the non-payment of the amounts in question. At issue were principles concerning annuities and the interpretation of statutes. The Court held that if an annuity was granted in consideration of the grantee's giving up his business to the grantor, it need not be registered under the Grants of Life Annuities Act, 1777 (17 Geo III c 26), which (by its preamble) sought to control the "pernicious practice of raising money by the sale of life annuities" by requiring the registration of grants of life annuities. The reason was that the Act applied only to an annuity granted or sold for a pecuniary consideration alone and not, eg, as here, for a consideration which was the giving up of a business. The decision subsequently became a leading one in the nineteenth century: see, eg, Hood v Burlton (1792) 2 Ves Jun 29, 30 ER 507; Hutton v Lewis, Clerk \& Others (1794) 5 TR 639, 101 ER 356; Doe, on demise of Johnstone v Phillips (1808) 1 Taunt 356, 127 ER 871; and see, also, Hunt 1796: 334-343; Blayney 1817: 5556; and Espinasse 1824: 39.

230 See Philip 1981: 469; CA, BO 122/60/1 (1801)

231 As to which see n 258 infra.

232 See, eg, NA, HCA 49/33-11/a for Wittenoom's bills, receipts, payments and accounts for the registry of the Cape Vice-Admiralty Court, Nov 1799-Jan 1801, containing some forty individual items, mainly receipts by the Court staff (about all of whom more shortly) for wages and reimbursements paid by Wittenoom. For instance, item 4, dated 9 Feb 1800, acknowledges the 
capacity. ${ }^{233}$ In November 1800 , he was succeeded in that position by BG Rouviere, but continued to act in the Court not only as a proctor, but also as the King's Proctor. ${ }^{234}$ In the latter capacity, he also took charge of the prosecution in the Piracy Court in June 1798 in the Princess Charlotte matter, ${ }^{235}$ while in the proceedings in that Court in March 1801 in the Chesterfield matter, he acted for the defence. ${ }^{236}$ In December 1800 , he further applied on behalf of the firm of Walker \& Robertson for a letter of marque for their ship, the Lady Yonge, signing the application as "Advocate \& Proctor for the Petitioners". ${ }^{237}$ In 1801, Wittenoom received permission to practise as a notary. 238

After Wittenoom left the Cape, probably sometime in 1803, he is listed as a proctor having an office in Doctors' Commons in London, ${ }^{239}$ and he and his former colleague, Rouviere, are then mentioned as proctors practising in the Vice-Admiralty Court on the island of Malta from at least $1810 . .^{240}$

receipt by Ziervogel of some Rds 270 for his time and attendances at the Court up to that date; item 18 acknowledges the receipt by Halaran of Rds16, being one month's salary from 9 Feb-9 Mar 1800; item 21, reflecting payment of Rds8 to Menzies and Rds6 to Rankin for their attendances at the registry on $22 \mathrm{Feb}$ and 9 Mar 1800; and in item 27, Rankin acknowledges the receipt of some Rds9 for his extra writing and attendance after hours on Saturdays and Sundays in Mar 1800. There are also items referring to payments to persons not (today known as) being (permanently) attached to the Court. For instance, item 35 reflects the payment of Rds40 to Thomas Carter (Philip 1981: 61 mentions that he was a former seaman, and at one time a tutor to the Rex family) for one month's wages on 6 Dec 1800, and item 40 reflects the payment of Rds36 to John Batten (see Philip 1981: 20), being three weeks' salary due on 10 Jan 1800.

233 See NA, HCA 49/35-2/a for official letters addressed to the Court's actuary (first Wittenoom and then Rouviere: see, again, n 208 supra).

234 See Cape Town Gazette of Sat 29 Nov 1800 concerning Wittenoom's replacement as registrar of the Vice-Admiralty Court, but indicating that he "will continue to act in that court as King's Advocate".

235 See CA, BO 36, 24; Mosse appeared for the defence: see, again, at n 101 supra.

236 See CA, BO 37, 17; Somers prosecuted: see, again, at n 111 supra.

237 See CA, BO 92, 43; earlier, in Jan 1799, he had applied as proctor for Capt Smart for a letter of marque for Hogan's Collector: see CA, BO 92, 27; as to these letters of marque, see again n 47 supra.

238 Philip 1981: 469, referring to a petition (CA, BO 122/60/1), dated 31 Oct 1801 from William Menzies (see n 299 infra), who had been instructed to apply again (an earlier request having been rejected) for permission for Wittenoon and George Rex to practise as notaries public. Menzies explained that Wittenoom had been appointed as actuary and examiner of the ViceAdmiralty Court. Both applicants, it seems, had refused to undergo any examination by the local Court of Justice in view of their English qualifications and had therefore not been admitted to practice before that and other civil courts in the colony, although they were, on the basis of those qualifications, naturally entitled to do so before the (British) Vice-Admiralty Court.

239 See the British Imperial Calendar for 1811 at 229. However, that does not mean he was then actually practising there, for the list also mentions the proctor David Jennings, who was practising at the Cape at the time, as well as George Rex, who had long ago ceased practising as such.

240 See the Royal Kalendar, and Court and City Register for England, Scotland, Ireland, and the Colonies for the years 1811-1816 (there is no mention of proctors for the years 1818-1820); also, eg, the Gentleman's and Citizen's Almanack .... for ... 1815 at 156; and see, again, at n 216 supra. 
Where and when Wittenoom died, is still unknown. ${ }^{241}$ His will, dated January $1814,{ }^{242}$ provided that if he died in London, he wished to be buried in the parish church of St Leonard's in Shoreditch, in the family vault there, but an otherwise pleasant afternoon spent searching in the church, proved fruitless.

Thomas Wittenoom and his wife, Elizabeth Waters, had several children. The eldest son was John Wanstead Burdett Wittenoom, later to be appointed as the first clergyman in Western Australia ${ }^{243}$ and the first in a long line of influential Australian Wittenooms. ${ }^{244}$ Another son was Charles Dirck Wittenoom, an artist and journalist. ${ }^{245}$ There was also a daughter, Elizabeth (or Eliza), who had accompanied the eldest son, John, to Australia. ${ }^{246}$ The death of Thomas's widow in Australia on 27 June 1846 was announced as that of "Elizabeth, relict of Thomas Wittenoom, esq. Senior Proctor of the Vice-Admiralty Court of the Cape of Good Hope and Malta".

\section{The practitioners}

There were never many practitioners at the Cape Vice-Admiralty Court. In October 1801, for instance, there were only four - Wittenoom, Mosse, Rowles and Somers - when they collectively sent a letter to the deputy registrar, Rouviere, objecting to

241 His date of death is given as 1813 in O'Brien \& Statham-Drew 2009: chart 1. However, a website devoted to South African theatres (see http://esat.sun.ac.za/index, accessed 9 Oct 2014) has it that one Thomas Wittenoom, a Cape Town businessman of (indirect) Dutch descent, who died in 1821, was one of the shareholders by whom a section of the "Boereplein" in town was donated for the building of a theatre, which later became the African Theatre; his five shares in the theatre were offered for sale from his estate on 17 Feb 1821.

242 See NA, PROB 11/1551/350 for the will of "Thomas Wittenoom of Southampton, Hampshire".

243 John Burdett Wittenoom (1789-1855) arrived in Perth in Jul 1829, accompanied by his mother, Elizabeth Waters (Thomas's wife, 1771-1845), his sister Elizabeth Burdett Wittenoom, and four children, his wife Margaret May having died in 1823. He was the only clergyman in the colony until 1836 and also established a classical school in Perth. The Wittenoom family became wellknown in Western Australia for its commercial, farming and civic interests. Of John Wittenoom's children, the eldest son, John Wanstead Burdett, born in England in 1815, became a mounted policeman and later a prospector in Victoria, and died some time after 1851 in South Africa after his family had lost touch with him. Another son, Frederick Wanstead Dirck (1821-1863), became a public servant in the colony. And the youngest son, Charles Wanstead (1824-1866), was in turn the father of Edward Horne Wittenoom (1854-1936), who became minister of mines in Western Australia. The infamous and doomed asbestos-mining town of Wittenoom is named after him (or at least after the family).

244 On the Australian Wittenooms, see further Cranfield 1963; Cameron 1979; and O'Brien \& Statham-Drew 2009; see also RE Cranfield "Wittenoom, John Burdett" in Australian Dictionary of Biography available at http://adb.anu.edu.au/biography/ (accessed 9 Oct 2014).

245 There is a biography of him on the website "Design and Art Australia Online", available at http:// www.daao.org.au (accessed 9 Oct 2014).

246 Her likeness is reproduced in O'Brien \& Statham-Drew 2009: 63. 
the possibility that the fees in Instance causes would no longer be permitted to be charged at the same rate as those in Prize causes. ${ }^{247}$

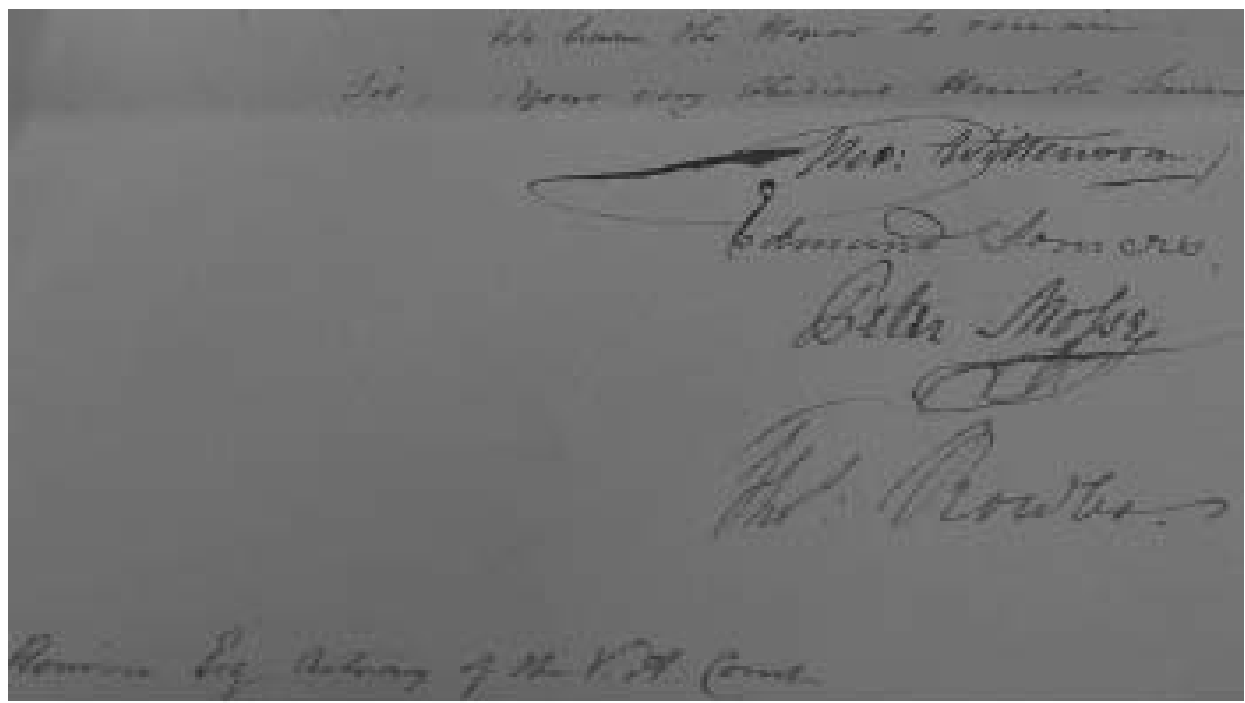

[Signatures to a letter from the practitioners at the Cape Vice-Admiralty Court, to deputy registrar Rouviere, 26 Oct 1801 (NA, HCA 49/35(2), bundle (4))]

Peter Mosse was an Irishman who had been a Protestant clergyman and then became a Catholic priest, but was too fond of horse-racing and other expensive pleasures and in consequence had to quit his home country. He came to the Cape where he made a livelihood by keeping a coffee-house and a billiard table in town. Later he was appointed as a clerk in the Colonial Secretary's office, and from there he rose to the practice of law, appearing as counsel in the Vice-Admiralty Court. ${ }^{248} \mathrm{He}$ is listed as an advocate in the Vice-Admiralty Court from $1800,{ }^{249}$ but may have been practicing before then. ${ }^{250}$

247 See NA, HCA 49/35(2) bundle (4), letter of 26 Oct 1801. They asked Rouviere to inform Judge Holland that, first, no complaint had been received from any parties involved in such litigation; secondly, that the issues were as complicated or more in Instance causes than in Prize causes; thirdly, that the same was true of the trouble in attending such causes; and fourthly, that there was great expense involved in conducting such business at the Cape. Accordingly, they requested that the fees in Instance causes should continue as before.

248 Lady Anne Barnard Diaries vol 1: 311 (Oct 1799) refers to him as "originally clergyman - then clerk - next lawyer - afterwards coffee house keeper"; see, also, Philip 1981: 290-291, who has him as clerk in the office of Andrew Barnard in 1797 at $£ 72$ p/a.

249 See the African Court Calendar for 1801; he is not mentioned in 1802. Mosse may also have been involved as a litigant: see CA, NCD 1/14/1125 (notarial protocol, special power of attorney granted concerning a case involving Peter Mosse, 1800).

250 Barnard Diaries vol 2: 115 n 45 refers to him in Oct 1799 as a lawyer in the Admiralty Court. 
After he commenced practising in the Vice-Admiralty Court, Mosse continued acting as prize agent for the captors of prizes as he had done before; ${ }^{251}$ occasionally he acted as an examiner (of witnesses on behalf) of the Court. ${ }^{252} \mathrm{He}$ also defended the accused before the Piracy Court in the Princess Charlotte matter in 1798. ${ }^{253}$

He was apparently on good terms with Judge Holland to whom he sold a slave in $1798 .{ }^{254}$

However, Mosse, who retained his fondness for horse racing and gambling, ${ }^{255}$ became involved in the Jessup affair, which Lady Anne Barnard ${ }^{256}$ referred to as "another Strange Higgleday Piggleday business going on" and which her husband ${ }^{257}$ called "another strange piece of Business". The upshot of the affair was that the inspector of customs, Henry James Jessup, who had opposed an order from Governor Yonge, ${ }^{258}$ and who further did not endear himself to the Governor by sarcastically

251 See Philip 1981: 290-291, acting as a prize agent in a May 1798 petition on behalf of naval capts Tod and Gardener respecting a prize being adjudicated in the Court: see CA, BO 112/66/1 (1798); for other legal involvements, see, eg, CA, NCD 1/26/492 (1799), NCD 1/48/374 (1799), NCD $1 / 48 / 421$ (1799), and NCD 1/14/1125 (1800).

252 See, eg, his petition to Gen Francis Dundas, dated 27 Mar 1799 (referred to in Philip 1981: 290291), stating that "the Judge of Vice-Admiralty Court here, having thought proper to appoint me Examiner of said court, and being of the opinion that its duty should be best performed by a notary, has desired me to apply to you for power to act as such"; Dundas replied that his application had not been made in the correct form.

253 See CA, BO 36, 23, where it appears that Mosse was willing and permitted to undertake conduct of the prisoners' defence (although they were not entitled to counsel) and that he promptly obtained an adjournment to allow him to prepare. Wittenoom prosecuted in this matter: see, again, at $\mathrm{n} 101 \mathrm{f}$ supra.

254 See CA, NCD 1/39/358 (1798).

255 Barnard Diaries vol 1: 311 (Oct 1799) noted that Mr Moss, as she referred to him, the advocate in the Admiralty Court, had bought a favourite horse of Col Cooke (Samuel Cooke, of the 8th Light Dragoons: Philip 1981: 74), "now dead of brandy, having run his race", and that even though his son rode his horse, Mosse lost at the races at the Turf Club.

256 Barnard Letters: 243 (14 May 1800).

257 Fairbridge 1924: 203-204 (letter Andrew Barnard to Earl Macartney, 14 May 1800).

258 Governor Yonge had granted permission to some merchants to ship and re-export to England certain Eastern goods on board the Young Nicholas. The goods had earlier, in 1798, been seized as prize on board the Danish ship, the Christianus Septimus (see NA, HCA 49/27 (1799) for the prize papers), and had then been restored to the merchants by the Vice-Admiralty Court. However, customs official and searcher, Jessup, thought that the Governor's order was contrary to the words and spirit of the applicable legislation and the monopoly granted by the charter of the East India Co. In Apr 1800, Jessup therefore took possession of the goods in question - worth some $£ 12000$ - on board the Young Nicholas and, supported by a legal opinion he had obtained from Mosse (see Theal $R C C$ vol 3: 161-162), he opposed the permission and the express orders of the Governor. The merchants immediately complained to Yonge. There was little doubt that Jessup had acted unlawfully and that Yonge did have the power to make the temporary arrangement he had until such time as a decision was received from London. By mid-1800, London had fully confirmed Yonge's actions, thus removing any uncertainty on the matter: see Theal $R C C$ vol 3: 199-206 (letter War Office to Governor Yonge, 28 Jul 1800) at 204-205. On the Jessup affair, see further the documentation reproduced in Theal $R C C$ vol 3: 152-184. 
commenting on the latter's accompanying proclamation, ${ }^{259}$ was simply suspended until the Crown's pleasure was known and ultimately did not leave the colony until $1803 .{ }^{260}$ Mosse - as well as proctor Pontardent ${ }^{261}$ - though, was banished from the Cape in April 1800, because the legal opinion he had given Jessup on the legality of Yonge's order and proclamation was considered improper and inflammatory.

Although Yonge was right and Jessup, and by association Mosse, wrong, ${ }^{262}$ there was a feeling that for all his faults ${ }^{263}$ Mosse's punishment was somewhat harsh; he had, after all, merely - in a professional capacity - drawn a legal opinion and should not have been censured because it turned out to be wrong. ${ }^{264}$

But Yonge clearly thought differently of Mosse. In explaining the affair to Henry Dundas, he wrote that he had been informed that Mosse was "a Man of Genius many ways" and that he had been practising in the Vice Admiralty Court "where", Yonge continued, "I am sorry to say there is a very great want of able Counsel". ${ }^{265}$ After Mosse had fired off several petitions concerning his banishment, ${ }^{266}$ he obtained

259 He said that Yonge's proclamation was "a green proclamation", alluding to the fact that the collector of customs, John Hooke Green (Philip 1981: 154), had boasted that he had had a share in drafting it, "under a young governor": see Fairbridge 1924: 204 (letter Andrew Barnard to Earl Macartney, 14 May 1800).

260 See Philip 1981: 208: Jessup, who may have been an American, was in 1798 appointed as the chief searcher in the Customs Department, but was suspended by the Governor for exceeding his authority and for acting in legal matters assuming the functions of an attorney. By May 1801, Jessup remained "on the watch for letters as he hopes to re-instate him, from England" (Fairbridge 1924: 280, letter Lady Anne Barnard to Earl Macartney, 27 May 1801). From Jun 1801 until Oct 1802 he sent various requests and petitions for the payment of his salary since his suspension, as well as for back-pay. He seems to have left the Colony in 1803: see Theal RCC vol 5: 167-168 (letter Governor Francis Dundas to Lord Hobart, 1 Mar 1803).

261 For his part in the affair, see n 278 infra.

262 Andrew Barnard regarded Yonge's treatment of Jessup as correct: officials had to obey the Governor's orders, even if they were illegal: see Barnard Letters: 243-244.

263 Lady Anne Barnard, for one, suggests (Barnard Diaries vol 2: 115 (28 Apr 1800)) that Jessup had hired Mosse as his counsel "as a sort of private negociator" to obtain a bribe from the merchants. See, also, Styles 2003: 149. Arkin 1960: 204 n 130 refers to Mosse as "the wily Irish advocate".

264 Lady Anne Barnard Letters: 243 (14 May 1800) explained that Mosse "as council" [to Jessup] gave an opinion that the Governor had infringed the relevant statutes and was "sent off for the terms in which his opinion is given"; Andrew Barnard (Fairbridge 1924: 203, letter to Earl Macartney, 14 May 1800) explained that Mosse had been approached by Jessup "for a legal opinion" and in it opined that the Governor had exceeded his powers by issuing a proclamation which was not binding.

265 See Theal $R C C$ vol 3: 152-154 (letter Governor Yonge to Henry Dundas, 12 May 1800, which contains most of the details concerning Mosse referred to earlier). He added, somewhat unnecessarily, that, because of his high living, Mosse was virtually without means at the time ("He appears to be not worth $£ 5$ in the World").

266 See Theal 1880, vol 3: 16 May 1800 (Mosse petitions to be informed of the reason for the Governor's order that he should leave the colony); 23 Jul 1800 (Mosse requesting Andrew Barnard to procure a suspension of the order for him to leave the colony); 23 Oct 1800 (a further petition from Mosse concerning the order given to him to leave the colony); 9 Jan 1801 (a petition from Advocate Mosse not to be banished from the colony, giving an account of his life and the services performed); 28 Oct 1801 (Mosse solicits employment in connection with the suppression of disturbances in the interior). 
permission early in 1801 to remain in the colony ${ }^{267}$ and seems only to have left two years later. ${ }^{268}$

Another advocate and examiner in the Vice-Admiralty Court, at least in 1801, was one Edward Somers, of whom nothing more is known. ${ }^{269}$

Better known was Thomas Rowles, likewise an advocate and examiner practising in the Vice-Admiralty Court. ${ }^{270}$

Born in Westminster, London, in 1777, he first arrived at the Cape in 1800 and was granted final permission to remain in the colony in November 1801. Although slated to take charge of the prosecution before the Piracy Court in March 1801 in the Chesterfield matter, the registrar, George Rex, informed the Court that Rowles had declared his intention to resign his appointment by reason of another professional engagement and Edward Somers was then appointed as counsel for the prosecution in his place. ${ }^{271}$

Rowles left the Cape in 1803, but he returned in 1807 as the "King's Proctor, and Agent for the Receiver General Comptroller, and Solicitor of all the Rights and Perquisites of Admiralty at the Cape of Good Hope", ${ }^{272}$ so becoming one of very few legal practitioners active in the Vice-Admiralty Court in both periods of British rule. He was in 1807 also appointed as secretary to the Court of Appeals for both Criminal and Civil Cases, a position he would hold until his death in $1826 .{ }^{273}$

On 29 December 1811, aged thirty-three, Rowles married the seventeen-year old Elisabeth Christina, the youngest daughter of the late Arend de Waal, a Company official. Three weeks later, on 19 January 1812, he became related to the Admiralty Judge at the time, George Kekewich, a widower likewise then aged thirty-three, when the latter married one of Elizabeth's older sisters, Catharina Cornelia; ${ }^{274}$ the

267 Philip 1981: 290-291.

268 See Cape Town Gazette of 2 Jun 1803 for an advertisement by Mosse that, as he intended leaving the colony by the first convenient opportunity, those having claims upon him should apply to him for satisfaction at Hudson's Hotel.

269 He is mentioned in the African Court Calendar for 1802, but not in that for 1801; see, also, Philip 1981: 394. He is not to be confused with Dr Edmund Somers, a physician and director of the military hospital: see Barnard Diaries vol 1: 28 n 78; Barnard Journals 230 n 87; Barnard Letters: $252 \mathrm{n}$.

270 See Philip 1981: 365; Pama 1992: 130.

271 See CA, BO 37, 4.

272 See the African Court Calendar for 1808; in that of 1809, he is referred to as the "King's Proctor, and Agent for Droits".

273 It is highly probable that the advertisement of the sale of valuable and scarce books belonging to his widow, Mrs Rowles, in SA Commercial Advertiser of 24 Feb 1827, referred to that of her late husband. The legal texts listed were Jacob's Law Dictionary; Grotius on War \& Peace, and Beawes' Lex Mercatoria. Mrs Rowles had, in the Cape of Good Hope Government Gazette of 9 Feb 1827, made known her intention of leaving the colony for England, although the sale of the house of "Mrs, the Widow Thos Rowles" was advertised only in Cape of Good Hope Government Gazette of 9 Mar 1827. Rowles's will, dated 18 Jan 1812 and filed in 1826, is in CA, MOOC 7/1/98/01/23/1 (1812); in it he is referred to as the "secretary of the Court of Appeals".

274 See Botha 1962f: 266, 270. 
two lawyers were witnesses at each other's weddings. On occasion Rowles would also act as Judge in the Vice-Admiralty Court in the absence of his brother-in-law, while both were active in the Court of Appeals. ${ }^{275}$

Another practitioner who, like Rowles, was active in judicial circles at the Cape during both periods of British rule, was David Pontardent. ${ }^{276}$

Adescendant of a French Protestant family that had settled in London, Pontardent arrived at the Cape in 1797. He practiced as a proctor in the Vice-Admiralty Court and occasionally acted as its examiner until he, together with Mosse, ${ }^{277}$ got into trouble with Governor Yonge for his part in the Jessup affair ${ }^{278}$ and was banished from the settlement. In April 1800 Pontardent was also dismissed from his appointment as an examiner of the Vice-Admiralty Court on the instructions of Judge Holland. ${ }^{279}$ Although Pontardent protested against his banishment, ${ }^{280}$ generally considered to have been even more severe in his case than in that of Mosse, ${ }^{281}$ that was to no avail.

275 Rowles as secretary and Kekewich as assessor. Rowles also appears to have been involved in local commerce: see CA, CO 3871/12/1 (1809) for an application by William Wilberforce Bird, Hamilton Ross and Thomas Rowles to sell coffee then on board the ship, the Reliance.

276 Also Pontardant or Ponterdant; see Philip 1981: 328.

277 See n 255 supra.

278 According to Lady Anne Barnard (Letters: 243-244 (14 May 1800)), he was banished "for endeavoring to negociate a compromise between the partys which would have purchased $\mathrm{Mr}$ Jessops silence"; Styles 2003: 149 refers to Pontardent's attempt to conciliate the dispute as an unwarranted attempt to silence Jessup; Andrew Barnard (Fairbridge 1924: 203, letter to Earl Macartney, 14 May 1800) referred to Ponterdent as someone "who came out here lately with a Passport from the Secretary of State" and who had acted as Jessup's agent in endeavouring to persuade the merchants whose property was under seizure, to compromise the affair with Jessup.

279 See Theal RCC vol 3: 174-175 (letter Wittenoom to Pontardent, 30 Apr 1800, informing the latter of Judge Holland's decision "to dispense with your further Services as Examiner of the Vice Admiralty Court of this Colony", and explaining that, despite the fact that because of his banishment such dismissal was unnecessary, he was nevertheless pertinently dismissed to express the Judge's "indignation" at the unjustified use of his name by Pontardent in the Jessup matter; that was because Pontardent was "a person holding an Official Situation in the Court over which he [Holland] presides"). Holland himself wrote to Governor Yonge on 30 Apr 1800, enclosing Wittenoom's letter, should it be thought necessary to take further action against Pontardent in London: see Theal $R C C$ vol 3: 175.

280 See Theal $R C C$ vol 3: 175-176 (letter Pontardent to Wittenoom, 4 May 1800, alleging misrepresentation in that he had used the Judge's name - by intimating that he had heard that a difference of opinion existed between the Judge and Governor Yonge as to the legality of Jessup's seizure - confidentially in "a private Conversation" with two merchants who had shipped goods on board the Young Nicholas and who had asked his opinion; he nevertheless apologised for any indiscretion). Holland passed his letter on to Governor Yonge on 8 May 1800: see Theal $R C C$ vol 3: 178 .

281 Lady Anne Barnard (Letters: 244 (14 May 1800)) thought Pontardent was, after all, "acting only as a private friend ... between the partys, was not bound to any particular rigidity of Maxim as a public man is, in matters connected with the Laws". See, also, Barnard Diaries vol 2: 115 (28 Apr 1800 ) and 180 (2 Jul 1800), describing that Governor Dundas was miffed at his wife for having invited to her ball Mr Pontardent, "a person under his displeasure" (Pontardent and Lady Dundas had come out in the same ship, hence their acquaintance), but, Lady Anne remarked, Pontardent had not committed any crime, but had only offended politically and she did not think Lady Yonge would be justified for treating him with the neglect she ought to bear him if he had misbehaved in any shape after the loss of his money. 
Governor Yonge clearly did not regard him highly. In explaining the Jessup affair to Henry Dundas, Yonge wrote that he knew little of Mosse's accomplice, Pontardent, whom he did not name, apart from the fact that having "practiced as a lawyer in England", "he too practiced here as a lawyer in the Admiralty Court" and that those who know him "do not speak favourably of him". ${ }^{282}$

In April 1802, Pontardent, then in London, ${ }^{283}$ sought, on the basis of the injury he had suffered at the hands of Governor Yonge, an appointment as British consul at the Cape, now that the settlement was about to be restored to the Dutch, ${ }^{284}$ but his request seems to have been disregarded. ${ }^{285}$

Pontardent eventually arrived back in the colony in September 1806, without his wife and children. ${ }^{286} \mathrm{He}$ resumed his practice as a proctor in the Vice-Admiralty Court $^{287}$ and pursued his interests in matters botanical, ${ }^{288}$ until his intestate death in May 1825 at the age of fifty-nine. ${ }^{289} 290$

\section{The support staff}

Several persons were appointed as administrative personnel in the Vice-Admiralty Court. They are no less interesting than the officials and the practitioners whom they served.

282 See Theal $R C C$ vol 3: 152-154 (letter Yonge to Dundas, 12 May 1800).

283 Which may explain why he is not listed in the African Court Calendars for 1801 and 1802.

284 See Theal RCC vol 4: 282 (letter Pontardent to Secretary of State, Lord Hobart, 21 Apr 1802).

285 In Feb 1803, John Pringle, formerly the East India Company agent at the Cape, was appointed as the British agent there: see Theal $R C C$ vol 5: 151-154.

286 His permission to return was dated 29 Apr 1806: see CA, GH 1/1, no 7 (1806).

287 His obituaries in Cape Town Gazette of 28 May 1825 and in Quarterly Oriental Magazine, Review and Register of Jul-Dec 1825 at cxxxvii, both mentioned that Pontardent had built up "a respectable and valuable practice at the Cape" during the last war.

288 See (1810) 31 Curtis's Botanical Magazine ... at 1238, noting that in 1809 Pontardent had sent a specimen of a plant species from the Cape to a collection in Kensington.

289 See Botha 1962f: 297, 301 n 23. His gravestone at one stage resided in the former Somerset Rd Cemetery, Cape Town; it was inscribed "PONTARDENT, David Esq., Proctor in H.M. Court of Vice-Admiralty in this Settlement. d. 26.5.1825, age 59": see Genealogical Society of South Africa Alphabetical Guide to Gravestones in the Somerset Road Cemetery, Cape Town, Cape (1 ed 1993) unpaged; Botha 1962b: 72. Incidentally, also listed as being buried there is Jackson Perring, for eight years deputy King's Advocate in Ceylon, who died at the Cape in Dec 1837 en route back to England.

290 Pontardent's estate (of which Admiralty Judge George Kekewich was one of the executors) included "six books": see CA, MOOC8/41.10. Upon his death, his children (his wife had predeceased him) in England enquired after any inheritance, and one Pearson, a family friend, made enquiries from Sergeants Inn on their behalf in July 1826: see NA, CO 48/86/311. 
Aegidius Benedictus (AB) Ziervoge ${ }^{291}$ was the Court's sworn translator and interpreter and also at times the messenger at the Court of Justice. ${ }^{292}$

Born in Uppsala, Sweden, on 21 August 1762, the son of a well-known professor at the university there, ${ }^{293}$ he left Sweden in 1786, moved to Amsterdam to learn commerce, and emigrated to the Cape of Good Hope in August 1789. There he was joined by his elder brother, Carel Ewald, and later by his cousin, Carel Samuel Fredrikzoon Ziervogel. ${ }^{294}$

In May 1800, he married a local widow, Beatrix Auret. ${ }^{295} \mathrm{He}$ had close personal ties with the Vice-Admiralty Court's marshal, George Rex. ${ }^{296}$ Ziervogel died in June 1818 , having only in the year before gotten around to requesting citizenship of the colony. ${ }^{297}$ One of his descendants, his grandson, was the well-known Cape Judge, EB Watermeyer. ${ }^{298}$

When Scotsman William Menzies arrived at the Cape in 1827 to take up his appointment as senior puisne judge on the bench of the newly created Supreme

291 See the "Ziervogel Family Tree", available at http://www.geocities.com/sa_stamouers/zievogel. htm (accessed 22 May 2002); also at http://family.itcouncil.biz (accessed 26 Apr 2012); "Stamvader

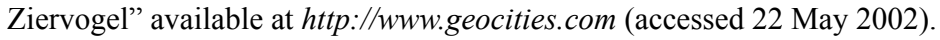

292 See, eg, the advertisements for judicial sales ordered by that Court he placed in Cape Town Gazette of 15 May 1802, 8 and 15 Jan 1803, and 12 and 19 Feb 1803.

293 His father was Ewald (Evald) Benedictus Ziervogel (1728-1765), author, professor of literary history, and librarian at the Royal Academy and at the University of Uppsala. He was also a famous numismatist and the author of, amongst other works, Dissertatio academica, de nummaria, eiusque in historia Suiogothica usu ... (2 vols, 1745 and 1750, Uppsala) - see (1852) 1-5 Notes and Queries 462 - and Dissertatio academica, usum rei nummariae in historia literaria domesticis examplis declaramus (1754, Uppsala). I inspected copies in the British Library. AB had four siblings: Elisabeth Brigitta Christina (b 1752, who later married Andries Hemberg, a professor of law); Samuel Frederik (b 1756, who in 1803 became the secretary to the Court of Law after having studied in Edinburgh); Carel Ewald (b 1756); and Christina Juliana (b 1768).

294 In 1791, AB was a scribe in the naval victualling yard and also did duty as a postman: see Moree 1998: 140 and again $n 148$ supra. AB and Carel Ewald were also the local representatives of the Swedish East India Company, and an advertisement in Cape Town Gazette of 1 Oct 1801 directed claims on two company ships to be directed to them; they also acted as agents at the Cape for two Swedish ships - the Vester Gothland and the Gustavus III - in requesting permission to land and sell locally damaged cargo from the former and concerning the detention of the latter: see CA, BO 119/95 (1800), BO 119/98 (1800), and BO $119 / 101$ (1800). Carel Ewald died in Aug 1803: see Cape Town Gazette of 20 Aug 1803.

2951800 Cape Directory 165.

296 Rex was the godfather of his cousin's daughter (Helena Elizabeth, 1803-1867); he advertised and then also bought Rex's property, Schoonder Zicht, in the Gardens: see Kaapsche Courant of 12 May 1804 and AB and Rex jointly owned the boat, the Young Phoenix, in 1809: see, further, Storrar 1974: 108

297 See CA, CO 3907/186 (memorial from EB requesting burghership, 1817).

298 Egidius Benedictus Watermeyer (1824-1867) was the second son of Frederick Stephanus Joubert Watermeyer and his wife, Ana Maria (1804-1864), the eldest child and only daughter of AB Ziervogel: see Nathan 1934: 165; F St L S 1935: 142. 
Court, he was not the first of that name to be involved with the administration of justice at the Cape.

In February 1798, the twenty-six-year old William Menzies ${ }^{299}$ arrived here on the Belvedere, a fellow passenger of Judge Holland and proctor Wittenoom. After a brief stint in the customs office, he was appointed a clerk in the Vice-Admiralty Court's registry at an annual salary of $£ 150 .{ }^{300}$

In April 1801, Menzies resigned from his duties at the Court and requested permission to be admitted to practise as a notary public. ${ }^{301}$ His request was turned down on the grounds of his short period of local residence. ${ }^{302}$ Further petitions followed in May and again in November 1801. Nevertheless, Menzies appears to have been active as a representative (the recipient of notarial powers of attorney) in several matters, including one involving prize agent William Proctor Smith. ${ }^{303}$ Although Menzies signed an oath of submission to the Batavian government in November 1803, he gave notice in June 1805 of his intention to leave the colony.

William Menzies may have been the uncle of Judge William Menzies. ${ }^{304}$

299 He should be distinguished from Capt James Menzies, who served at the Cape 1800-1802: see Barnard: 197 n 19; Philip 1981: 278

300 See Philip: 1981: 278. In Jan 1799, he signed a loyal address to Governor Dundas; in Feb 1799, his then boss, the collector of customs John Hooke Green (see n 259 supra), complained about Menzies' conduct when he reacted strongly to a reprimand from Green; this was followed up by a memorial from Menzies regarding his dispute with Green (see CA, BO 114/01/112/1 (1799)), to which Governor Dundas's favourable response elicited Menzies' gratitude (see CA, BO 114/01/121/1 (1799)).

301 He had also, earlier, applied for a certificate of eligibility for employment in the colony: see CA, BO 114/01/120/1 (1799).

302 See CA, BO 120/01/17/1 (1801). His memorial stated that he had resigned from his employment at the Court on the appointment of Rouviere as (deputy) registrar and examiner because of "finding himself disappointed in obtaining in the said Court of Vice Admiralty that promotion and countenance which [he] looks upon as entitled to from his long services". He applied to be admitted as notary on the basis of "[h]is personal knowledge of the Laws and Practice of this Colony", regarded himself as "fully adequate to undertaking the office of a Notary Public" and was ready to provide such security as would be required.

303 See CA, NCD 1/15/1530 (1801), in which Menzies acted on behalf of Samuel Hudson and appointed JB Hoffman to deal with a case involving Smith; see, also, NCD 1/16/1608 (1802), NCD 1/16/1624 (1802), NCD 1/16/1658 (1802).

304 See Botha 1962d: 20 n 19; Storrar 1974: 149. A search in the Menzies' family papers and correspondence in the Caird Library at the National Maritime Museum, Greenwich (NRA 8845 Menzies) and in the National Records of Scotland, Edinburgh (NRA 35726) may shed further light on this. I did not have access to a small work by Maraquita Fasson (the Judge's granddaughter), entitled Some Family Notes Regarding the Late Mr Justice W Menzies ... (n/d), nor to David Matthewes "American descendants of William Menzies, solicitor of customs at Leith", published in (1994) vol 17 The Menzies Clan Magazine, and mentioned on the Scots Genealogy Society

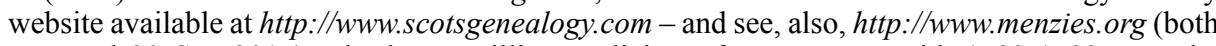
accessed 30 Sep 2015). The latter William, solicitor of customs at Leith 1782-1793, was the Judge's grandfather and thus, possibly, clerk William's father. Grandfather William's eldest son (of twelve children), John (1763-1825), succeeded his father as first solicitor of customs in Leith, and was the Judge's father: see Botha 1962d: 3, who mentions the incident in 1814 in Edinburgh involving Sir Walter Scott dining with the future Judge at the latter's residence and in the company of Menzies" "worthy father and uncle" (see, also, Kahn 1976), which is probably as close as we are at this stage able to come to William the clerk. 
Other clerks in the Vice-Admiralty Court during the First British Occupation were Thomas Spencer in 1797; ${ }^{305}$ William Henry Sturgis, who arrived from England in 1796 and may have been appointed in Menzies' place in 1801;306 and Joseph Ranken. ${ }^{307}$ Finally, there was the Irishman Edward Halaran, the court's messenger and crier at least from 1800 until its closure in $1803 .{ }^{308}$ Although persons are sometimes mentioned as the "vendu master of the Vice-Admiralty Court", it would appear that there was no such position; one of the several official auctioneers at the Cape merely also acted for the Court in its sales as and when required..$^{309}$

\section{The closure of the Vice-Admiralty Court}

By the Treaty of Amiens of 27 Mar 1802, ${ }^{310}$ concluded between England and the French and Batavian republics, article VI restored the Cape of Good Hope to the Dutch as it was before the war. ${ }^{311}$ It was further agreed that " $[\mathrm{t}]$ he ships of every

305 See Philip 1981: 397.

306 Idem 1981: 408; and African Court Calendar for 1802. His appointment came to an end in 1803; in Nov of that year he signed the oath of submission to the Batavian regime and he is mentioned as a clerk in the victualling office from 1806-1810. He is not the Joseph Sturgis (1798-1838) who, in 1828, became a partner of attorney John Samuel (who was also a proctor in the Vice-Admiralty Court) in a Cape Town firm of attorneys later to be known as Fairbridge, Ardene \& Lawton: see MacSymon 1990: 14, 17, 22.

307 See Philip 1981: 336-337. He was later a storekeeper in Long Market St (see Cape Town Gazette of 3 Oct 1810) and a partner in the firm of Ranken \& (Alex) Scott, which advertised public sales (see, eg, Cape Town Gazette of 7 Jun 1811) at their premises in Long St. He died in 1827: see Cape Town Gazette of 31 Aug 1827.

308 Halaran (often also Halloran) arrived at the Cape in 1795 as a soldier, was discharged at his own request, remained in the colony with his wife when his regiment left it, and obtained his position at the Vice-Admiralty Court after a recommendation by Col Dundas. He stayed on after 1803 (his memorial to the Raad van Politie in 1803 concerned his having been left without employment on the closure of the Court), and died at the Cape in 1807: see Philip 1981: 159-160; Leibbrandt 1905: 598-599. Halaran is not to be confused with the Irish clergyman and military chaplain at the Cape from 1795, Edward Thomas Hallaran (d 1805: see Philip 1981: 162; Botha 1962f: 293; "Hallaran, Edward" available at http://www.southafricansettlers.com (accessed 17 Aug 2015)), although some sources referred to seem to do so as each has its own Irishman married to the same woman, Elizabeth Maria Orgo (Hugo?). Nor should he be confused with Dr Laurence Hynes Halloran, colonial (military and naval) chaplain, 1807-1810, and teacher: see Philip 1981: 162.

309 Thus, Clemen(t)s Matthiessen, a member of the Court of Justice and President of the Lombard Bank, was said to have been, by 1801, also "Vendu Master of the Vice-Admiralty Court" (Barnard Diaries vol 1: $39 \mathrm{n}$ 14). While Matthiessen was indeed a vendu master (the official appointed to conduct public auctions) at the Cape in 1801, he was one of four (the others were Lind, Bergh, and Moulds) and may merely have been appointed, whether for the time being or on an ad hoc basis, also to conduct prize sales on behalf of the Vice-Admiralty Court.

310 See Theal $R C C$ vol 4: 274-275; Eybers 1918: 12-13.

311 This had to happen within three months (see art XII), but the hand-over only took place on $21 \mathrm{Feb}$ 1803: see Theal $R C C$ vol 5: 156 for the relevant proclamation by Governor Francis Dundas. 
description belonging to the other Contracting Parties shall have the right to put in there, and to purchase such supplies as they may stand in need of as heretofore, without paying any other duties than those to which the Ships of the Batavian Republic are subjected".

While local institutions continued as before, British institutions closed down and ceased operations. British subjects had the option of staying on, but most returned home. Thus, although officials charged with, for example, the administration of justice, were required to continue the functions of their offices, this naturally did not apply to the Vice-Admiralty Court which was not a local, but rather a British court. The Court ceased its operations and its officers and practitioners, with a few exceptions, left the Cape.

Those who left and who, like Judge Holland, received their salaries from the civil list, were paid in advance to 30 June $1803 .{ }^{312}$

In anticipation of the end of British rule, Judge Holland wrote to London about the effect that would have on the Vice-Admiralty Court. ${ }^{313}$ He thought it would be necessary to make some provision, whether by an article in a treaty or in some other form, "for the termination of Causes pending in the Vice Admiralty Court of this Colony ... that will not in all Probability be finally determined upon previous to the Surrender of the Cape", as well as for cases then on appeal. The Court would cease to have jurisdiction unless special provision was made. The same applied to securities taken by the Court for various purposes, including for letters of marque. Finally, he assumed it would meet with governmental approval "that the Records of the Court should be transmitted to the registry of the High Court of Admiralty" and, unless instructed otherwise, he would make arrangements for that "previous to quitting the Colony".

Although nothing seems to have been arranged as regards pending cases, the matter was eventually resolved.

In The Picimento, ${ }^{314}$ a Portuguese vessel was captured by a privateer in 1801 and brought for adjudication before the Cape Vice-Admiralty Court. The Court pronounced a sentence of restitution with costs and damages. The captor appealed against the sentence, but failed to prosecute the appeal in time. The Lords Commissioners of Appeal in Prize Cases then declared the appeal deserted and remitted the cause. However, before the Vice-Admiralty Court's sentence could be carried into final execution, the Cape was given up in terms of the Treaty of Amiens, the Court abolished, "and the records of the Court of Vice-Admiralty were removed, and deposited in the Registry of the High Court of Admiralty" in London. On an application that the High Court of Admiralty carry the Vice-Admiralty Court's

312 See Theal $R C C$ vol 5: 162 (letter Governor Dundas to Lord Hobart, 1 Mar 1803) at 168.

313 See Theal $R C C$ vol 4: 216-217 (letter Holland to Lord Hobart, 1 Feb 1802).

314 (1803) 4 C Rob 360, 165 ER 640; for the prize papers, see NA, HCA 49/21/4 (prize papers of the ship Picimento, otherwise Pensamento Felice. 
decree into execution, the question arose whether the High Court of Admiralty had jurisdiction to interfere in a cause already determined in another court and to carry into effect the judgement of that other court.

After the Lords Commissioners had refused to give a ruling in the matter - they only had appellate jurisdiction and as they had dismissed the appeal, they could not become involved de novo - the High Court of Admiralty held that it did have a general jurisdiction sufficient to aid the process of the Cape Vice-Admiralty Court in order to prevent a total failure of justice.

As mentioned, the records of the Cape Vice-Admiralty Court were sent to London where they still reside, ${ }^{315}$ leaving only an odd assortment of documents of the first Vice-Admiralty Court in the Cape Archives. ${ }^{316}$

315 The records of the Cape Vice-Admiralty Court, 1795-1805, are currently held in the National Archives in Kew (NA). In the archives of the High Court of Admiralty in the NA, the Cape Court's records (451 of them) reside in HCA 49/1-49/44. In the main, they are of Prize (and a few Instance) proceedings in the Court and include abstracts, affidavits, answers, appraisements, bills of lading, cargo lists, certificates of registration, claims, day books, decrees of delivery and possession, decrees of unlivery (ie, discharge), depositions, examinations, interrogatories, invoices, letters of attorney, libels, a list of adjudications, memoranda, monitions, passports, petitions, powers of attorney, powers of procuration, seamen's articles, ships' manifests, stipulation bonds, and translations. Miscellaneous papers are taken up in HCA 49/33(11), HCA 49/35(2), and HCA 49/40(2)-49/44. Also of interest are: HCA 49/38(1) (the Court's Muniment Book, 1797); HCA 49/38(2)-(7) (the Court's Assignation Book (Prize), 1798-1802); HCA 49/38(8) (its Bail Book (Instance), 1798); HCA 49/38(9) (its Letter Book, 1799); HCA 49/39(1)-(4) (the registers of powers of attorney, letters of marque and company); HCA 49/39(5)-(9) (the Court's Registry Account Books, 1798); and HCA 49/39(10)-(11) (its Registry Day Books, 1799). Appeals heard by the High Court of Admiralty are to be found in HCA 32/1836. Other holdings of interest in the NA are: ADM 5/43, 5/50 (Cape Vice-Admiralty Court); FO 95/640 (Cape Vice-Admiralty Court: captors' expenses); PC 1/65/34 (order for warrants appointing the judge and other officers, 1796); and PRO 30/42/16/11 (powers of and opinions on the Cape Vice-Admiralty Court).

316 In the Cape Archives (CA), the following are of interest. First there are the archives of the ViceAdmiralty Court (VAC), 1799-1887, in six vols (3 bound, 3 unbound). Only incidental and unsystematic records of the Court's activities during the First British Occupation remain. See Guide to the Arranged Archives in the Cape Archives Depot vol 1 (2 ed, Feb 1986, Pretoria) at 62-65; Inventory 1/146: VAC Papers, arranged by archivist JC Visagie (1967); and C Graham Botha Brief Guide to the Various Classes of Documents in the Cape Archives for the Period 16521806 (1918, Cape Town) at 54-60. The VAC series comprises: (1) VAC 1: Miscellaneous Court Papers, 1800-1816, including letters received and despatched, 1799-1822; extracts from Court proceedings, Feb 1800-Dec 1822; documents that were exhibits in proceedings (249 pp); (2) VAC 2: Cases, $1800-1859$, and also two undated letters addressed to Pontardent ( 25 separate folders); (3) VAC 3: Cases and contracts, 1799-c1806, including $R v$ Brooks \& Mortlock, Mar 1801 (in 5 separate folders); (4) VAC 4: Instance Assignation Book, 1825-1883 (277pp, indexed); (5) VAC 5: Ledger of Prize Cases, 1840-1887 (65pp); and (6) VAC 6: Bills of costs, registrar's accounts, c 1804-1823 (in 8 separate folders). Other items of interest in the CA include, in the BO (British Occupation, 1795-1803) series: BO 35: Letters received from the Vice-Admiralty Court, Feb 1799-Sep 1802 (1 vol; 189pp); BO 36: Proceedings of the Piracy Court, Jun-Jul 1798 (1 vol, 96pp); BO 37: Proceedings of the Piracy Court, Mar-Apr 1801 (113pp); BO 38: Correspondence with prize agents, Nov 1795-Jun 1798 (47pp); BO 92: Miscellaneous documents, no 2: applications for letters of marque, Jan 1799-Nov 1801 at 26-63 (130pp); and BO 230: Miscellaneous documents, no 5: (written, some printed) instructions to governors from the Secretary of State concerning ships having letters of marque, Jan 1797-Apr 1799 at 1-111 (111pp). 


\section{JP VAN NIEKERK}

After the Batavian interlude, during which a Commercial Court ("Kamer van Commercie") settled commercial, including maritime, disputes, ${ }^{317}$ the British returned in January 1806 and soon re-instituted their Vice-Admiralty Court.

\section{BIBLIOGRAPHY}

Albertson, L "Mutiny on the Princess Charlotte, 1798" (19 Jul 2002) available at http://archiver. rootsweb.anchestry.com (accessed 4 Aug 2014)

Albertson, L "Princess Charlotte and confusion at the Cape" (19 Jul 2002) available at http:// archiver.rootsweb.anchestry.com (accessed 4 Aug 2014)

Anon (1963) “The order book of captain Augustus Brine, RN, 1797-1815” Quarterly Bulletin of the SA Library 17: 75-86 and Quarterly Bulletin of the SA Library 18: 17-26

Arkin, Marcus (1960) "John Company at the Cape. A History of the Agency under Pringle (17941815) Based on a Study of the 'Cape of Good Hope Factory Records"' Archives Year Book for South African History 2: 178-344

Arnould (2013) Law of Marine Insurance and Average 18 ed by Jonathan Gilman, Robert Merkin, Claire Blanchard \& Mark Templeman (London)

Barnard, Lady Anne (Letters) (1973) The Letters of Lady Anne Barnard to Henry Dundas from the Cape and Elsewhere 1793-1803 Together with Her Journal of a Tour into the Interior and Certain Other Letters ed by AM Lewin Robinson (Cape Town)

Barnard, Lady Anne (Journals) (1974) The Cape Journals of Lady Anne Barnard 1797-1798 ed by AM Lewin Robinson with Margaret Lenta \& Dorothy Driver [VRS Second Series no 24] (Cape Town)

Barnard, Lady Anne (Diaries) (1799) The Cape Diaries of Lady Anne Barnard 1799-1800 vol 1 ed by Margaret Lenta \& Basil le Cordeur [VRS Second Series no 29] (Cape Town)

Barnard, Lady Anne (Diaries) (1800) The Cape Diaries of Lady Anne Barnard 1799-1800 vol 2 ed by Margaret Lenta \& Basil le Cordeur [VRS Second Series no 30] (Cape Town)

Blayney, Frederick (1817) A Practical Treatise of Life Annuities; ... (London)

Böeseken, AJ (1986) Uit die Raad van Justitie 1652-1672 (Pretoria)

Botha, C Graham (1962a) "Cape records of the South Sea pirates" in General History and Social Life of the Cape of Good Hope [vol 1 Collected Works] (Cape Town): 42-52

317 The Court (or Chamber), consisting of a president (advocate Rogier Gerard van Polanen, succeeded by Rudolph Anthony de Salis) and four members (Oloff Godlieb de Wet, Clemen(t)s Matthiessen (see, again, n 309 supra), Johannes Andreas (later sir John) Truter, and David George Anosi), was instituted on 24 May 1804 to settle commercial disputes arbitrarily following "eene verkorte wyze van procedeeren" during which no legal representation was allowed, and against the outcome of which there was no appeal. The Court had jurisdiction in "[a]lle verschillen over zaaken den handel betreffende", whether between inhabitants, between them and foreigners temporarily present in the port or on board ships in the roadstead, or between such foreigners (the latter a wide jurisdiction familiar to Admiralty lawyers): see Kaapse Plakkaatboek vol 5: 143-145 (referring to the body as a "Handelshof"); Immelman 1955: 10, 23-25 (referring to it as a Chamber of Commerce). 
Botha, C Graham (1962b) "Some monumental inscriptions Cape of Good Hope" in General History and Social Life of the Cape of Good Hope [vol 1 Collected Works] (Cape Town): 70-73

Botha, C Graham (1962c) "Administration of the Cape of Good Hope, 1652-1834" in General History and Social Life of the Cape of Good Hope [vol 1 Collected Works] (Cape Town): 231-244

Botha, C Graham (1962d) "The Honourable Willam Menzies 1795-1850" in History of Law, Medicine and Place Names in the Cape of Good Hope [vol 2 Collected Works] (Cape Town): 1-21

Botha, C Graham (1962e) “The public archives of South Africa 1652-1910" in Cape Archives and Records [vol 3 Collected Works] (Cape Town): 113-222

Botha, C Graham (1962f) "Extracts from register of deaths at the Cape of Good Hope, 18161826" in Cape Archives and Records [vol 3: Collected Works] (Cape Town): 290-301

Boucher, Maurice \& Nigel Penn (eds) (1992) Britain at the Cape 1795 to 1803 (Houghton)

Bourguignon, Henry J (1987) Sir William Scott, Lord Stowell. Judge of the High Court of Admiralty, 1798-1828 (Cambridge)

Brenton, Edward Pelham (1837) The Naval History of Great Britain from 1783 to 18362 vols (London)

Bridges, George Wilson (1828) The Annals of Jamaica vol 1 (London)

Brooks, Michael Franklin (1802) Trial of the Master and Supercargo of the Merchant Ship Chesterfield Charged ... with Treasonable Correspondence with the Enemies of Great Britain ... (London)

Butterfield, Agnes M (1938) "Notes on the records of the Supreme Court, the Chancery, and the Vice-Admiralty courts of Jamaica" Historical Research 16: 88-99

Cameron, Catherine WM (1979) Frederick Francis Burdett Wittenoom, Pastoral Pioneer \& Explorer 1855-1939: A Biographical Sketch (Perth)

Cordingly, David (2008) Cochrane the Dauntless. The Life and Adventures of Admiral Thomas Cochrane, 1775-1860 (London)

Cranfield, RE (1963) The Wittenoom Family in Western Australia: A Brief Account of the Lives of Members of the Wittenoom Family who left England in 1829 (place of publication not mentioned)

Crump, Helen J (1931) Colonial Admiralty Jurisdiction in the Seventeenth Century [No 5 Royal Empire Social Imperial Studies] (London)

Davey, Arthur (1988) "Naval headquarters, Table Bay, 1795-1803" CABO. Historical Society of Cape Town 4(3): 14-16

De Kock, MH (1924) Selected Subjects in the Economic History of South Africa (Cape Town)

De Villiers, Charl Jean (1967) Die Britse Vloot aan die Kaap, 1795-1803 (MA, University of Cape Town)

De Villiers, Charl Jean (1969) “Die Britse Vloot aan die Kaap, 1795-1803” Archives Yearbookfor SA History 32(1): 1-145

De Vos, Wouter (1992) Regsgeskiedenis, met 'n Kort Algemene Inleiding tot die Regstudie (Cape Town) 


\section{JP VAN NIEKERK}

Dictionary of South African Biography (1968-1987) 5 vols (Cape Town)

Dugan, James (1966) The Great Mutiny (London)

Dunlap, Andrew (1836) A Treatise on the Practice of Courts of Admiralty in Civil Causes of Maritime Jurisdiction ... (Philadelphia)

Du Plessis, Willemien, and Nic Olivier (2014) “'n Samevloei van twee regstelsels: Siviele prosesreg in die Kaapse howe: 1806-1828" in Marita Carnelley, Shannon Hoctor \& André Mukheibir (eds) De Jure Gentium et Civili. Festschrift in Honour of Eltjo Schrage (e-publication, Nelson Mandela University, Port Elizabeth): 9-44

Edwards, AB (1972) “A conflict of jurisdiction” Codicillus 12(1): 42-43

Espinasse, Isaac (1824) A Treatise on the Law of Actions on Statutes, .... (London)

Eybers, GW (1918) Select Constitutional Documents Illustrating South African History 17951910 (London)

Fairbridge, Dorothea (1924) Lady Anne Barnard at the Cape of Good Hope 1797-1802 (Oxford)

Featherstone, David (2009) "Counter-insurgency, subalternity and spatial relations: Interrogating court-martial narratives of the Nore mutiny of 1797" SA Historical J 61: 766-787

Feldbaek, Ole (1973) "Dutch Batavia trade via Copenhagen 1795-1807. A study of colonial trade and neutrality" Scandinavian Economic History Review 21: 43-75

Freund, William M (1989) "The Cape under the transitional governments, 1795-1814" in Richard Elphick \& Hermann Giliomee (eds) The Shaping of South African Society, 1652-1840 (Cape Town): 324-357

F St L S (1935) “Mr Justice EB Watermeyer” SALJ 52: 135-142

Gerber, Jill Louise (1998) The East India Company and Southern Africa: A Guide to the Archives of the East India Company and the Board of Control, 1600-1858 Appendix: vol 2 (D Phil thesis, University College, London)

Gibb, Arthur Ernst (1890) The Corporation Records of St Albans ... (St Albans)

Goldblatt, Robert (1984) Postmarks of the Cape of Good Hope: The Postal History and Markings of the Cape of Good Hope and Griqualand West, 1792-1910 (Cape Town)

Giliomee, Hermann (1975) Die Kaap tydens die Eerste Britse Bewind 1795-1803 (Cape Town)

Gregory, Desmond (1996) Malta, Britain, and the European Powers, 1793-1815 (Cranbury, NJ)

Griffiths, RJH (2002) "Navigator ... and inventor, discoverer, merchant, privateer .... The career of an eighteenth century seaman under White Ensign and Red and the tale of the discovery of two sets of 'Mortlock Islands"” Mariner's Mirror 88: 196-201, updated version available at http://www.mortlock.info/encyclopaedia/slands (accessed 1 Jun 2010)

Hall, John E (1809) The Practice and Jurisdiction of the Courts of Admiralty ... (Baltimore)

Hassam, John T (1880) Notes and Queries Concerning the Hassam and Hilton Families (Boston)

Heese, HF (1994) Reg en Onreg: Kaapse Regspraak in die Agtiende Eeuw (Bellville)

Horwitz, D (1997) Disreputable Fellows: Prisoners and Graffiti from the Castle, Cape Town (honours dissertation in Archaeology, University of Cape Town)

Hough, Barry, and Howard Davis (2008) "Coleridge as public secretary in Malta: The surviving archives" The Coleridge Bulletin (NS) 31: 90-101

Hunt, William (1796) A Collection of Cases on the Annuity Act relative to the Enrolment of Memorials (London) 
Immelman, RFM (1955) Men of Good Hope. The Romantic Story of the Cape Town Chamber of Commerce 1804-1954 (Cape Town)

Jurgens, AA (1943) The Handstruck Letter Stamps of the Cape of Good Hope from 1792 to 1853 and the Postmarks from 1853 to 1910 (Cape Town)

Kaapse Plakkaatboek 6 vols (1944-1961) ed by MK Jeffrey (vols 1-3) and SJ Naude (vols 4-6) (Cape Town)

Kahn, Ellison (1976) “Sir Walter Scott and Menzies” SALJ 93: 94-95

Knight, Roger (2008) "Politics and trust in victualling the Navy, 1793-1815" Mariner's Mirror 94: 133-149

Laidler, PW (1939) The Growth and Government of Cape Town (Cape Town)

Lawrence-Archer, JH (1875) Monumental Inscriptions of the British West Indies ... (London)

Leach, MacEdward (1960) "Notes on American shipping based on records of the Court of ViceAdmiralty of Jamaica, 1776-1812" American Neptune 20: 44-48

Leibbrandt, HCV (1905) Precis of the Archives of the Cape of Good Hope: Requesten (Memorials) 1715-1806 vol 1: A-E (Cape Town)

Linder, Adolphe (1997) Swiss at the Cape of Good Hope 1652-1971 (Cape Town)

Lloyd, Christopher (1947, 1998 ed) Lord Cochrance. Seaman, Radical, Liberator. A Life of Thomas, Lord Cochrane, 10th Earl of Dundonald (New York)

MacSymon, RM (1990) Fairbridge Ardene \& Lawton. A History of a Cape Law Firm (Cape Town)

Marshall, Samuel (1808) A Treatise on the Law of Insurance .... 2 ed (London)

Moree, Perry (1998) 'Met Vriend die God Geleide'. Het Nederlands-Aziatisch postvervoer ten tijde van die Verenigde Oost-Indische Compagnie (Zutphen)

Namier, Lewis, and John Brooke (1964) The History of Parliament: The House of Commons, 1754-1790 vol 1: Members A-J (London)

Nathan, Manfred (1934) “The old Cape bench and bar" SA Law Times 3: 165-166

O'Brien [née Wittenoom], Jacqueline, and Pamela Statham-Drew (2009) On We Go: The Wittenoom Way: The Legacy of a Colonial Chaplain (Perth)

Oxford Dictionary of National Biography (2004, various subsequent online eds) available at http://www.oxforddnb.com

Pama, C (1992) British Families in South Africa. Their Surnames and Origins (Cape Town)

Percival, Capt Robert (1804) An Account of the Cape of Good Hope ... (London)

Philip, Peter (1981) British Residents at the Cape 1795-1819. Biographical Records of 4800 Pioneers (Cape Town)

Roos, J de V (1897) “The plakaat books of the Cape” Cape LJ 14: 1-23

Rosenthal, Eric (1954) "Mutiny at Simonstown" in Eric Rosenthal Cutlass and Yardarm (Cape Town): 67-75

Sainty, JC (1975) Office Holders in Modern Britain. IV: Admiralty Officials 1660-1870 (London)

Schuhmacher, W Wilfried (1977) “Some Danish Indiamen at the Cape of Good Hope” Mariner's Mirror 63: 231-232

Seth, Suman (2014) "Materialism, slavery, and The History of Jamaica" Isis. A J of the History of the Science Society 105: 764-772 
Smith, Herbert A (1927) “The legislative competence of the dominions" SALJ 44: 545-553

SP (1933) "Long family of Jamaica” Notes \& Queries 165: 339-340

Spilhaus, M Whiting (1966) South Africa in the Making 1652-1806 (Cape Town)

Stokes, Anthony (1783) A View of the Constitution of the British Colonies in North America and the West Indies ... (London)

Storrar, Patricia (1974) George Rex: Death of a Legend (Johannesburg)

Stroud Dorothy (1966) Henry Holland: His Life and Architecture (London)

Styles, Michael H (2003) Captain Hogan. Sailor, Merchant, Diplomat on Six Continents (Fairfax Station, VA)

Taylor, Stephen (2016) Defiance. The Life and Choices of Lady Anne Barnard (London)

Theal, George McCall (1880) Catalogue of Documents Sept 1795-Feb 1803 in the Collection of the Colonial Archives, Cape Town (Cape Town)

Theal, George McCall (1895) Documents Copied by Theal (London)

Theal, George McCall Records of the Cape Colony (RCC) (1897-1905) 34 vols (London)

Ulrich, Nicole (2011) Counter Power and Colonial Rule in the Eighteenth-Century Cape of Good Hope: Belongings and Protest of the Labouring Poor ( $\mathrm{PhD}$ thesis, University of the Witwatersrand)

Ulrich, Nicole (2013) “International radicalism, local solidarities: The 1797 British naval mutinies in Southern African waters" International Review of Social History 58: 61-85

Van Blommestein, Joan (1998) “Lady Anne Barnard's visit to Simon's Bay 24-9-1797 and the RN Mutiny" Bulletin of the Simon's Town Historical Society 20: 53-54

Van der Merwe, Petrus Johannes (1984) Regsinstellings en die Reg aan die Kaap van 1806-1834 (LLD thesis, University of Western Cape)

Van Niekerk, JP (1994) "Marine insurance claims in the Admiralty Court: An historical conspectus" SA Merc LJ 6: 26-62

Van Niekerk, JP (2005) "The First British Occupation of the Cape of Good Hope and two prize cases on joint capture in the High Court of Admiralty" Fundamina. A Journal of Legal History 11: 155-182

Van Niekerk, JP (2010) "George Rex of Knysna: A civil lawyer from England and first marshal of the Vice-Admiralty Court of the Cape of Good Hope, 1797-1802" Fundamina. A J of Legal History 16(2): 486-513

Van Niekerk, JP (2015a) “Denis O’Bryen: (Nominally) second marshal of the Vice-Admiralty Court of the Cape of Good Hope, 1807-1832" Fundamina. A J of Legal History 21(1): 142184

Van Niekerk, JP (2015b) “Of naval courts martial and prize claims: Some legal consequences of commodore Johnstone's secret mission to the Cape of Good Hope and the 'battle' of Saldanha Bay, 1781 (Part 1)" Fundamina. A J of Legal History 21(2): 392-456

Van Niekerk, JP (2016) "Of naval courts martial and prize claims: Some legal consequences of commodore Johnstone's secret mission to the Cape of Good Hope and the 'battle' of Saldanha Bay, 1781 (Part 2)" Fundamina. A J of Legal History 22(1): 118-154

Van Zyl, DH (1983) Geskiedenis van die Romeins-Hollandse Reg (Durban) 
Visagie, GG (1969) Regspleging en Reg aan die Kaap van 1652 tot 1806, met 'n Bespreking van die Historiese Agtergrond (Cape Town)

Walker, Eric A (1957) A History of South Africa 3 ed (London)

Wells, Roger (1983) Insurrection. The British Experience 1795-1803 (Gloucester)

Wilkinson, Clive (2005) "The non-climatic research potential of ships' logbooks and journals" Climatic Change 73: 155-167

Wright, Philip (1966) Monumental Inscriptions of Jamaica (London)

Wright, Philip (ed) (2004) Lady Nugent's Journal of Her Residence in Jamaica from 1801 to 1805 4 ed (Jamaica)

Yonge, CD (1863) The History of the British Navy .... 2 vols (London)

\section{Case law}

Angelique, The (1801) 3 C Rob (App) 7, 165 ER 497

Argun, MT v Master and Crew of the MT Argun 2004 (1) SA 1 (SCA)

Atalanta, The (1808) 6 C Rob 440, 165 ER 991

Boehm \& Others $v$ Bell (1799) 8 TR 154, 101 ER 1318

Carr \& Josling v Montefiore (1864) 5 B \& S 408, 122 ER 883

Crespigny $v$ Wittenoom \& Another (1792) 4 TR 790, 100 ER 1304

Doe, on demise of Johnstone v Phillips (1808) 1 Taunt 356, 127 ER 871

Hood v Burlton (1792) 2 Ves Jun 29, 30 ER 507

Hope, The (23 April 1803, HL), referred to in The Atalanta (1808) 6 C Rob 440, 165 ER 991 at 456-457, 997-998

Hutton v Lewis, Clerk \& Others (1794) 5 TR 639, 101 ER 356

Picimento, The (1803) 4 C Rob 360, 165 ER 640

Reward, The (1818) 2 Dods 265, 165 ER 1482

Robertson v French (1803) 4 Esp 246, 170 ER 707 (KB)

Robertson \& Thomson v French (1803) 4 East 130, 102 ER 779

Umbragio Obicini v Bligh (1832) 8 Bing 335, 131 ER 423

Yeaton v Fry 5 Cranch 335, 9 US 335 (US Dist Col, 1809) 